\title{
Lithogeochemistry of Mineralized and Altered Rock Samples from the Northern Talkeetna Mountains, South-Central Alaska
}

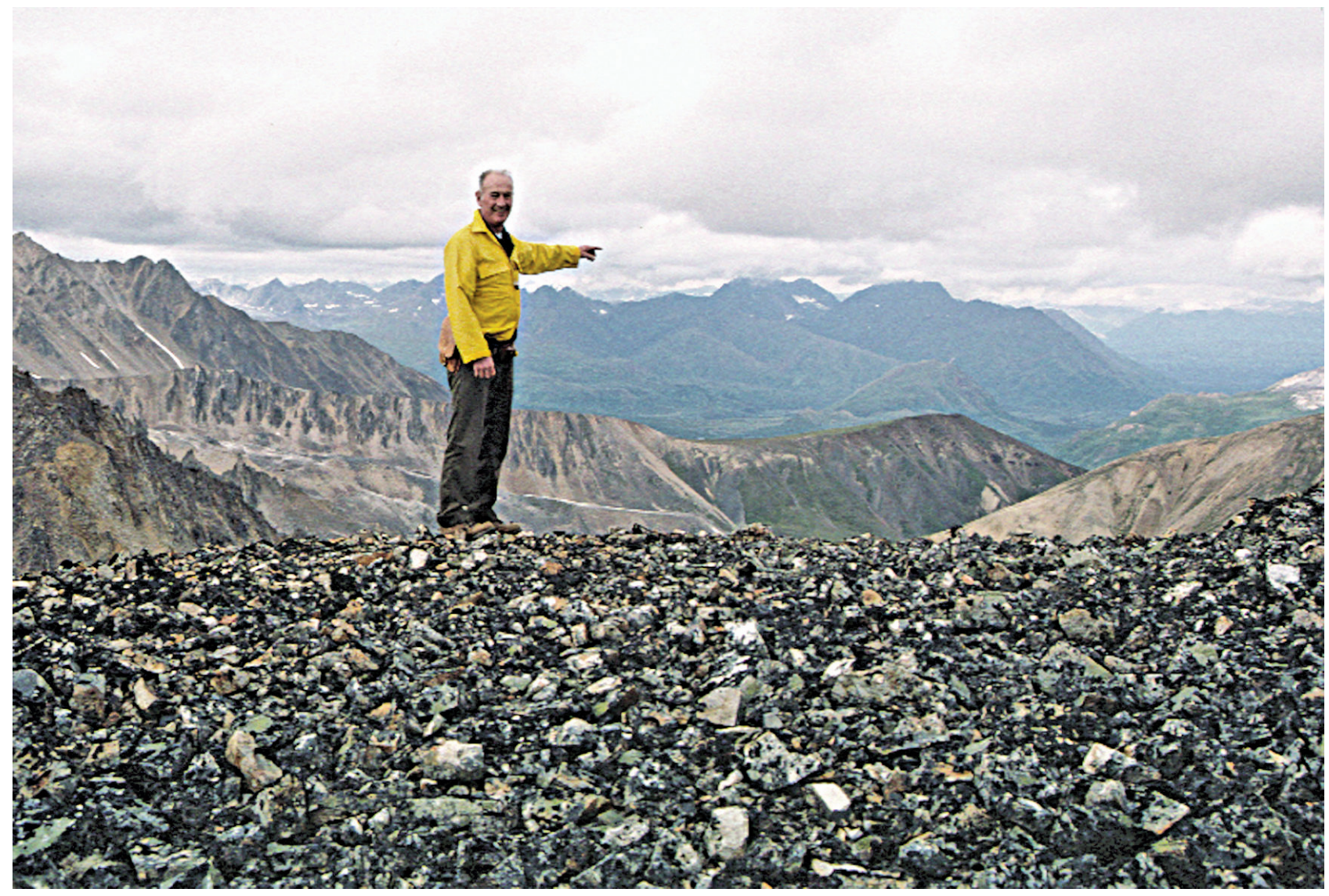

Scientific Investigations Report 2011-5162 
Rugged landscape in the northern Talkeetna Mountains, Alaska. USGS geologist Skip Cunningham is standing on Tertiary granite, which also forms the ridge behind him. Skip points to the buff-colored ridge of Tertiary volcanic rocks, center right. View to the north, across the East Fork Chulitna River. USGS photo taken in 2002 by Jeanine Schmidt. 


\section{Lithogeochemistry of Mineralized and Altered Rock Samples from the Northern Talkeetna Mountains, South- Central Alaska}

By Thomas D. Light and Jeanine M. Schmidt

Scientific Investigations Report 2011-5162 


\title{
U.S. Department of the Interior KEN SALAZAR, Secretary
}

\author{
U.S. Geological Survey \\ Marcia K. McNutt, Director
}

U.S. Geological Survey, Reston, Virginia: 2011

This report and any updates to it are available online at: http://pubs.usgs.gov/sir/2011/5162/

For more information on the USGS - the Federal source for science about the Earth, its natural and living resources, natural hazards, and the environment, visit http://www.usgs.gov or call 1-888-ASK-USGS (1-888-275-8747).

For an overview of USGS information products, including maps, imagery, and publications, visit http://www.usgs.gov/pubprod

To order this and other USGS information products, visit http://store.usgs.gov

Any use of trade, product, or firm names is for descriptive purposes only and does not imply endorsement by the U.S. Government.

Although this report is in the public domain, permission must be secured from the individual copyright owners to reproduce any copyrighted material contained within this report.

Cataloging-in-publication data are on file with the Library of Congress (http://www.loc.gov/).

Suggested citation:

Light, T.D., and Schmidt, J.M., 2011, Lithogeochemistry of mineralized and altered rock samples from the northern Talkeetna Mountains, south-central Alaska: U.S. Geological Survey Scientific Investigations Report 2011-5162, 26 p. 


\section{Contents}

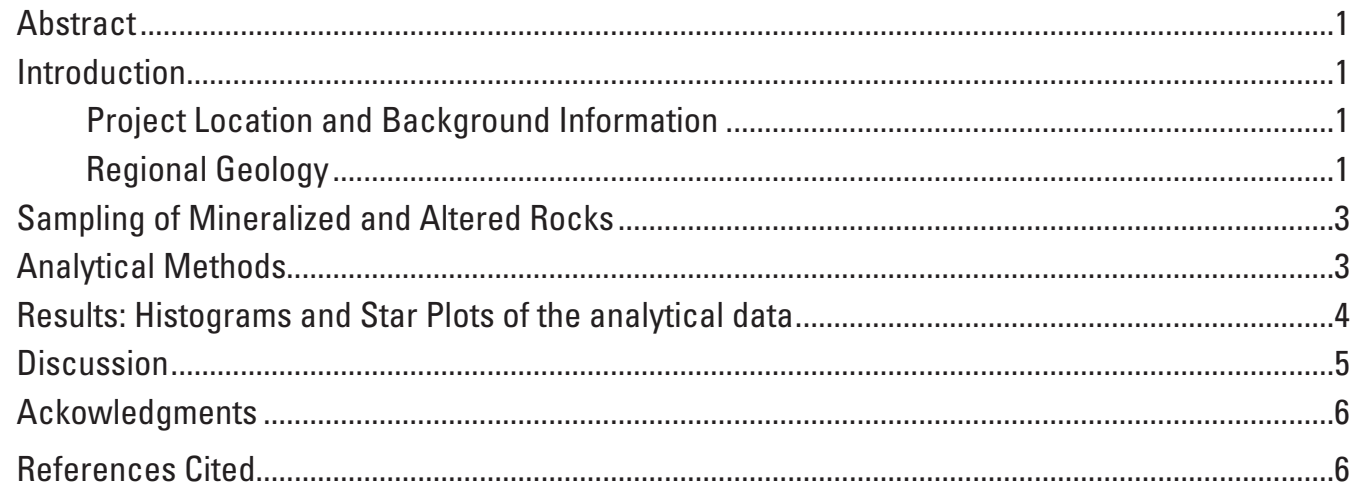

\section{Figures}

1. Map showing locations and field numbers (map numbers) of 201 altered, stained, sulfide-bearing, or visibly mineralized rock samples from the northern Talkeetna Mountains

2. Histograms showing distribution of $\mathrm{Ba}, \mathrm{Cu}, \mathrm{Pb}$, and $\mathrm{Zn}$ in samples from the northern

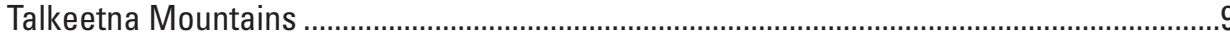

3. Star-plot map showing localities for samples containing high concentrations of $\mathrm{Ba}, \mathrm{Cu}, \mathrm{Pb}$, and $\mathrm{Zn}$

4. Histograms showing distribution of $\mathrm{As}, \mathrm{Au}, \mathrm{Bi}$ and $\mathrm{Sb}$ in samples from the northern Talkeetna Mountains.

5. Star-plot map showing localities for samples containing high concentrations $\mathrm{As}, \mathrm{Au}, \mathrm{Bi}$, and $\mathrm{Sb}$

6. Histograms showing distribution of $\mathrm{Ag}, \mathrm{Hg}$, $\mathrm{Li}$, and $\mathrm{Mo}$ in samples from the northern Talkeetna Mountains

7. Star-plot map showing localities for samples containing high concentrations

$\mathrm{Ag}, \mathrm{Hg}$, Li, and Mo.

8. Histograms showing distribution of $\mathrm{Be}, \mathrm{Mn}, \mathrm{Ti}$, and $\mathrm{W}$ in samples from the northern Talkeetna Mountains.

9. Star-plot map showing localities for samples containing high concentrations $\mathrm{Be}, \mathrm{Mn}, \mathrm{Ti}$, and $\mathrm{W}$

10. Histograms showing distribution of $\mathrm{Co}, \mathrm{Cr}, \mathrm{Ni}$ and $\mathrm{V}$ in samples from the northern Talkeetna Mountains.

11. Star-plot map showing localities for samples containing high concentrations $\mathrm{Co}, \mathrm{Cr}, \mathrm{Ni}$, and $\mathrm{V}$.

12. Histograms showing distribution of $\mathrm{Ce}, \mathrm{Eu}, \mathrm{Nd}, \mathrm{Y}$ in samples from the northern Talkeetna Mountains.

13. Star-plot map showing localities for samples containing high concentrations $\mathrm{Ce}, \mathrm{Eu}, \mathrm{Nd}$, and $\mathrm{Y}$. 


\section{Tables}

1. Analytical data for altered and mineralized rock samples from the northern Talkeetna Mountains, Alaska. (See attached spreadsheet file)

2. Analytical data for quality control samples from the northern Talkeetna Mountains, Alaska

3. Analytical methods and determination limits for rock samples from the northern Talkeetna Mountains, Alaska.. 


\section{Conversion Factors}

Inch/Pound to SI

\begin{tabular}{|c|c|c|}
\hline Multiply & By & To obtain \\
\hline \multicolumn{3}{|c|}{ Length } \\
\hline inch (in.) & 2.54 & centimeter (cm) \\
\hline inch (in.) & 25.4 & millimeter (mm) \\
\hline foot (ft) & 0.3048 & meter $(\mathrm{m})$ \\
\hline mile (mi) & 1.609 & kilometer (km) \\
\hline \multicolumn{3}{|c|}{ Mass } \\
\hline ounce, avoirdupois (oz) & 28.35 & $\operatorname{gram}(\mathrm{g})$ \\
\hline pound, avoirdupois (lb) & 0.4536 & kilogram (kg) \\
\hline \multicolumn{3}{|l|}{ SI to Inch/Pound } \\
\hline Multiply & By & To obtain \\
\hline \multicolumn{3}{|c|}{ Length } \\
\hline centimeter (cm) & 0.3937 & inch (in.) \\
\hline millimeter (mm) & 0.03937 & inch (in.) \\
\hline meter $(\mathrm{m})$ & 3.281 & foot (ft) \\
\hline kilometer (km) & 0.6214 & mile (mi) \\
\hline \multicolumn{3}{|c|}{ Mass } \\
\hline $\operatorname{gram}(\mathrm{g})$ & 0.03527 & ounce, avoirdupois (oz) \\
\hline kilogram $(\mathrm{kg})$ & 2.205 & pound avoirdupois (lb) \\
\hline
\end{tabular}

Horizontal coordinate information is referenced to the insert datum name (and abbreviation) here for instance, "North American Datum of 1983 (NAD 83)." 



\title{
Lithogeochemistry of Mineralized and Altered Rock Samples from the Northern Talkeetna Mountains, South-Central Alaska
}

\author{
By Thomas D. Light and Jeanine M.Schmidt
}

\begin{abstract}
Mineralized and altered rock samples collected from the northern Talkeetna Mountains, Alaska, were analyzed by two different inductively coupled plasma atomic-emission spectrometry (ICP-AES) methods for as many as 44 elements; by fire assay and either direct-coupled plasma (DCP) or atomic absorption spectrophotometry (AAS) for gold $(\mathrm{Au})$; by cold vapor atomic absorption (CVAA) for mercury $(\mathrm{Hg})$; and by irradiated neutron activation analysis (INAA) for tungsten (W). The analytical results showed that some samples contain high values of multiple elements and may be potential indicators of hydrothermal mineralization in the area.
\end{abstract}

\section{Introduction}

The U.S. Geological Survey (USGS) conducted a geologic mapping transect in the Talkeetna Mountains, south-central Alaska, from 1999 to 2002. In conjunction with this project, 201 altered or mineralized rock samples were collected and analyzed for 44 different elements. This report discusses the data from those geochemical analyses, presents histograms for selected elements, and illustrates the localities of samples with high values of selected elements within the project area.

\section{Project Location and Background Information}

The Talkeetna Mountains project surveyed an area approximately 100 kilometers $(\mathrm{km})$ long and as much as $60 \mathrm{~km}$ wide, extending from Broad Pass on the northwest to Gilbert Creek on the southeast (fig. 1). The study area included portions of the Healy A4 and A5 and Talkeetna Mountains C2, C3, C4, D2, D3, and D4 1:63,360-scale quadrangles. The transect crosses major geologic structures, stratigraphic units, and tectonic terranes in the northern Talkeetna Mountains. During the mapping project, geologists examined and sampled most known mines, prospects, and mineral occurrences (Rogers and Schmidt, 2003) within the project area (fig. 1). They also collected samples from any areas of altered, stained, sulfide bearing or visibly mineralized rocks encountered while mapping (Schmidt and Gamble, 2003). Both types of samples are collectively termed "altered" for the purposes of this report.

\section{Regional Geology}

The northern Talkeetna Mountains are located southeast of Mt. McKinley, near the axis of the "oroclinal" bend of the Alaska Range, where the orientation of the range changes from east-west to northeast-southwest. Geologic maps at 1:250,000 scale have been published for the Healy (Csejtey and others, 1992) and Talkeetna Mountains (Csejtey and others, 1978) quadrangles.

The study area includes Late Jurassic to Early Cretaceous flysch of the Kahiltna assemblage (Nokleberg and others, 1994). The Kahiltna overlaps the boundary between the Wrangellia composite tectonostratigraphic terrane to the southeast and the Yukon-Tanana and Farewell terranes with continental (North American) affinities to the northwest (Nokleberg and others, 1994; Glenn and others, 2007).

The Wrangellia terrane in the Talkeetna Mountains includes Mississippian to early Triassic fine-grained quartzose and fossiliferous calcareous sedimentary rocks overlain by flood basalts of the Middle to Late Triassic Nikolai Greenstone (Schmidt and Rogers, 2007). These Wrangellia rocks are intruded by a Middle Jurassic granodiorite/tonalite batholith (Schmidt and others, 2003), which is exposed in the southeastern part of the project area. Mesozoic Kahiltna flysch in the northwestern part of the study area overlies Late Triassic to Early Jurassic clastic marine sedimentary rocks and pillow basalts of the Honolulu Pass formation (Hampton and others, 2007). The flysch was derived from Wrangellia source rocks and deposited northwestward into a basin developed on transitional continental crust (Eastham and Ridgway, 2002; Glen and others, 2003; Hampton and others, 2003). The nonmarine Caribou Pass formation (Hampton and others, 2007) unconformably overlies Mesozoic flysch and provides a key marker for defining the transition from earlier widespread regional shortening to the strike-slip tectonics currently dominating the region. Paleocene felsic plutons derived from melted 


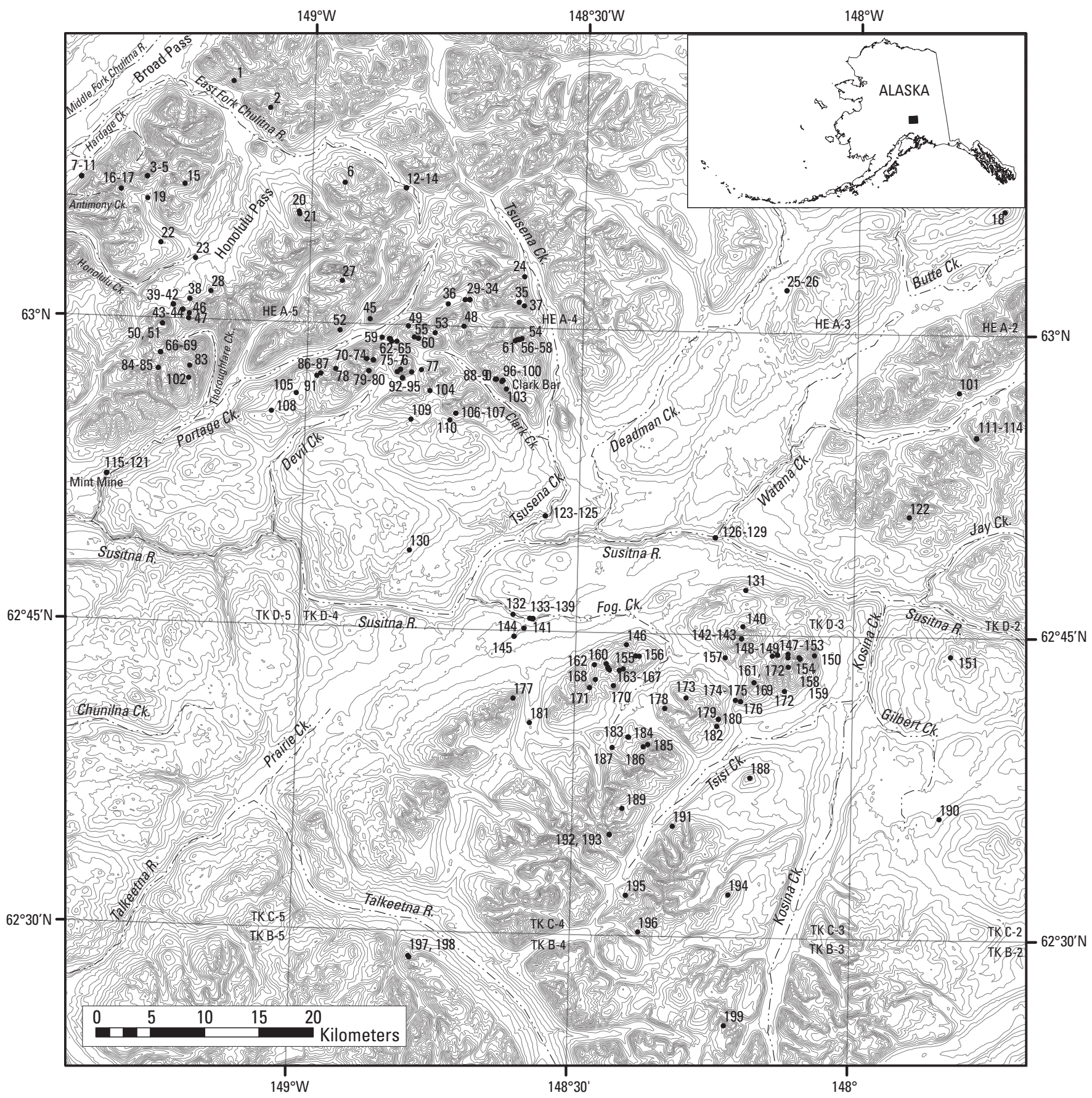

Figure 1. Map showing locations and field numbers (map numbers) of 201 altered, stained, sulfide-bearing, or visibly mineralized rock samples collected in 1999-2002 from the northern Talkeetna Mountains. [Note: Base map compiled from USGS Healy (HE) and Talkeetna (TK) 1:63,360 scale topographic maps; contour interval $200 \mathrm{ft}$.] 
flysch intruded the basin before the uplift of the Alaska Range. Distribution of Eocene volcanic rocks and Oligocene to Miocene nonmarine sediments within the study area is controlled by steep structures with both normal and strike-slip motion (O'Neill and others, 2003; Glen and others, 2007).

Mineral potential of the northern Talkeetna Mountains is related to the stratigraphic framework of the terranes and assemblages and to their structural, magmatic, and thermal history during aggregation, docking, rotation, and possible rifting along the southern Alaska continental margin. The configuration and history of the Wrangellia terrane are of particular interest because intrusive rocks related to the Nikolai Greenstone have the potential to host $\mathrm{Ni}, \mathrm{Cu}$, and platinumgroup-elements (PGE) deposits related to deep crustal fracturing and magma emplacement (Schmidt and Rogers, 2007).

There are several lode and placer mines, prospects, and mineral occurrences in the northern Talkeetna Mountains (Rogers and Schmidt, 2003). The Mint mine $\left(62.86^{\circ} \mathrm{N}\right.$, $149.37^{\circ} \mathrm{W}$ ) is on the west side of Portage Creek and comprises three short adits, 15 to 240 feet long, in blocky slate intruded by andesite dikes. The slate and andesite are both cut by quartz veins containing $\mathrm{Ag}, \mathrm{As}, \mathrm{Au}, \mathrm{Cu}$, and $\mathrm{Pb}$ (Rogers and Schmidt, 2003). Auriferous quartz-pyrite-stibnite veins cutting flysch are reported in Antimony Creek and Hardage Creek $\left(63.1^{\circ} \mathrm{N}, 149.3^{\circ} \mathrm{W}\right.$; Stevens, 2001). Sn-and Ag-bearing quartz veins with minor $\mathrm{Cu}, \mathrm{Pb}$, and $\mathrm{Zn}$ occur in Tsusena Creek (Stevens, 2001). $\mathrm{Ag}, \mathrm{As}, \mathrm{Au}, \mathrm{Cu}, \mathrm{Mo}, \mathrm{Pb}, \mathrm{Zn}$, and $\mathrm{Sn}$ have been reported from Honolulu Creek and nearby drainages (Light and others, 1989a,b; King and others, 1989; Balen, 1990). Near the southwest head of the East Fork Chulitna River $\left(63.1^{\circ} \mathrm{N}, 148.9^{\circ} \mathrm{W}\right)$, quartz veins containing $\mathrm{Sn}, \mathrm{Cu}, \mathrm{Zn}, \mathrm{Ag}$, and Mo in rhyolite near the contact with a granitic pluton suggest potential for porphyry Sn mineralization (Stevens, 2001). Placer claims are known to have been staked along Honolulu Creek, Little Honolulu Creek, and the East, Middle, and West Forks Chulitna River and nearby tributaries (Stevens, 2001). Placer Sn is reported from the East Fork Chulitna River (Rogers and Schmidt, 2003).

\section{Sampling of Mineralized and Altered Rocks}

As part of the of the USGS Talkeetna Mountains transect geologic mapping program in south-central Alaska from 1999 through 2002, a total of 201 rock samples (fig. 1) were collected and analyzed for various elements (table 1). All samples were single grab or composite chip samples of rocks from outcrop rubble or float. Each sample was collected because it contained metallic sulfide minerals (most commonly pyrite), was stained or altered, or was otherwise indicative of possible elevated metal contents. Sampled materials included quartz veins, gossans and iron-oxide stained rocks, breccias, clay-bearing rocks, and precipitates from cold springs and on fracture surfaces. Sample nos. 99ANA012A and 99ANS019A
(Map nos. 200 and 201 in table 1) lie several miles to the south of the others and are not plotted on figure 1. Analyses of background (unmineralized, unaltered) lithologic samples are not included in this dataset.

\section{Analytical Methods}

Samples were submitted through the USGS analytical chemistry facilities in Denver, Colorado, to XRAL Laboratories of Toronto, Ontario, for analysis under contract. Analytical results are shown in table 1 . Table 1 lists a map number for each sample; locations labeled with those numbers are plotted on figures $1,3,5,7,9,11$, and 13. In addition to the USGS and XRAL laboratories' quality-control samples and standards that were analyzed, 27 rock samples were split by the submitters and these separate splits were assigned different sample numbers and were submitted as blind duplicates in an independent test of analytical reproducibility. The duplicate sample results are listed in table 2 . In cases where multiple analytical methods produced data for the same element, the method with the lowest determination limit is listed in tables 1 and 2. For $\mathrm{Cu}, \mathrm{Pb}$, and $\mathrm{Zn}$, there were several samples for which the analytical results exceeded the upper determination limits of the 10-element ICP analysis; results for both 10-element and 40-element ICP analyses are listed for comparison.

Analytical methods included 10-element and 40-element inductively coupled plasma atomic emission spectrometry (ICP-AES); a fire assay (FA) method for gold; cold vapor atomic absorption (CVAA) for mercury; and irradiated neutron activation analysis (INAA) for tungsten. The following are descriptions of the analytical techniques used to determine the element concentrations.

The 10-element-suite ICP analyses used a partial extraction technique (Aliquot/MIBK) that has been modified and adapted for use with ICP-AES for the analysis of geologic materials (Detra, 2006). A hydrochloric acid-hydrogen peroxide mixture solubilizes metals not tightly bound in the silicate lattice of rocks, soils, and stream sediments. The metals are extracted by a 10 percent aliquot 336-diisobutylketone (DIBK) solution as organic halides. The separated organic phase is pneumatically aspirated into a multichannel ICP instrument, where the concentrations of the extracted metals (Ag, As, $\mathrm{Au}$, $\mathrm{Bi}, \mathrm{Cd}, \mathrm{Cu}, \mathrm{Mo}, \mathrm{Pb}, \mathrm{Sb}$, and $\mathrm{Zn}$ ) are determined simultaneously. It is important to note that this procedure is a partial digestion technique. Depending on element availability, results may be biased low when compared to other methods of analyses that have more complete digestion.

The suite of 40 major, minor, and trace elements in geological materials was determined by inductively coupled plasma-atomic-emission spectrometry (ICP-AES; Briggs, 2002). The samples were decomposed using a mixture of hydrochloric, nitric, perchloric, and hydrofluoric acids at low temperature. The digested samples are aspirated into the ICP-AES discharge, where the elemental emission signal is 
measured simultaneously for the 40 elements. Calibration is performed by standardizing with digested rock reference materials and a series of multielement solution standards (Detra, 2006).

Gold was determined by direct coupled plasma (DCP) or atomic absorption spectrophotometry (AAS) after collection by fire assay (FA) (Detra, 2006). An assay fusion consists of heating a mixture of the finely pulverized sample with about three parts of a flux until the product is molten. One of the ingredients of the flux is a lead compound, which is reduced by other constituents of the flux or sample to metallic lead. The latter collects all the gold, together with silver, platinum metals, and small quantities of certain base metals present in the sample, and falls to the bottom of the crucible to form a lead button. The gangue of the ore is converted by the flux into a slag sufficiently fluid so that all particles of lead may fall readily through the molten mass. The choice of a suitable flux depends on the character of the ore. The lead button is cupelled to oxidize the lead, leaving behind a dore bead containing the precious metals. The dore bead is then transferred to a test tube, dissolved with aqua regia, diluted to a specific volume and analyzed by DCP or atomic absorption spectrophotometry. The lower reporting limit for a 15 -gram sample charge is 5 parts per billion (ppb) by DCP and atomic absorption. The upper reporting limit is $10,000 \mathrm{ppb}$.

Mercury samples were analyzed by cold vapor atomic absorption (CVAA; Brown and others, 2002; Detra, 2006). A mixture of nitric and hydrochloric acids was used to digest 0.1 gram of sample. Potassium permanganate, sulfuric acid, and potassium persulfate are added to the solution, followed by a $\mathrm{NaCl}$-hydroxylamine solution, and then the solution is diluted to 25 milliliters. It is mixed thoroughly, allowed to settle, and then transferred to the auto-sampler rack of a Perkin-Elmer Flow Injection Mercury System, a cold-vapor atomic absorption mercury analyzer, which determines the mercury concentration in a solution after it has been liberated as vapor using a stannous chloride reducing agent. The absorption of the sample is measured using a mercury lamp at $253.7 \mathrm{~nm}$. The lower reporting limit is 0.02 parts per million (ppm) mercury in solid-phase samples.

Tungsten was analyzed by irradiated neutron activation analysis (INAA; Detra, 2006). Samples are irradiated together with a standard reference material in an epithermal flux. The samples are continuously rotated during the irradiation to ensure a homogeneous irradiation of each sample. Each batch of sample vials is wrapped in polyethylene with a nickel-chrome flux monitor attached to measure the neutron flux exposure to the samples. Four days after the irradiation, the samples are counted for approximately 1,000 seconds on high-performance germanium detectors. After decay correction, the concentration of tungsten in each sample is computed by comparing the standard concentration, number of counts for tungsten achieved for the standard, and the number of counts achieved for each sample. All spectra are collected in a Canberra multichannel analyzer and transferred to a computer for peak search analysis. In the case of tungsten, the number of counts in two energy areas of interest will be determined, $479.5 \mathrm{kev}$ and $685.7 \mathrm{kev}$. The lower limit of determination is $0.5 \mathrm{ppm}$.

Table 3 indicates the analytical method used for each element, the lower and upper determination limits for the chemical analyses, the numbers of qualified data (data outside the determination limits), and the estimated crustal abundance (Krauskopf, 1979) for each element. Table 3 also lists maximum and median values of the data for each element. The median value is that number above and below which half of the values fall; it is a measure unaffected by the censoring of the data (values above or below the determination limits) unless more than 50 percent of the data are censored.

\section{Results: Histograms and Star Plots of the Analytical Data}

Figures 2-15 are histograms and multielement map plots of analytical data for metallic and rare-earth elements of interest from the northern Talkeetna Mountains altered rock samples. The histograms illustrate the population distributions of individual elements; the multielement or star-plot maps show the localities of samples with high concentrations of those elements.

On the histograms, changes in the slope of the distribution or the presence of outliers above the estimated average crustal abundances of each element (Krauskopf, 1979) were used to define the threshold values (AT on the histograms) for high concentrations of individual elements to be plotted on the star plots. For comparison, the lower determination limits (LDL) for the analytical method and the estimated crustal abundance (CA) for each element are shown on the histograms. The highest values (above the cutoff level) for selected elements are highlighted in yellow in table 1; where two cutoff levels were used, the lower group (between the two cutoff levels) is highlighted in green in the table.

On the star plots, the individual elements are plotted in different orientations (rays) and the length of the ray indicates the range of concentration. Major rock-forming elements ( $\mathrm{Al}$, $\mathrm{Ca}, \mathrm{Fe}, \mathrm{K}, \mathrm{Mg}, \mathrm{Na}$, and $\mathrm{P}$ ), other elements with a high percentage of qualified (less than determination limit) values (for example, Ho, Sn, U), those that closely correlate with another element (for example, $\mathrm{Cd}$ and $\mathrm{Ga}$ following $\mathrm{Zn}$ ), and those of limited interest to mineral exploration (for example, $\mathrm{Yb}, \mathrm{Nb}$, $\mathrm{Sr}$ ) have not been plotted.

Figure 2 shows histograms for the concentrations of barium $(\mathrm{Ba})$, copper $(\mathrm{Cu})$, lead $(\mathrm{Pb})$, and zinc $(\mathrm{Zn})$, and figure 3 is a star-plot map showing the localities for which samples contained anomalous concentrations of those elements. These metals are characteristically associated with hydrothermal mineralization. In the Talkeetna Mountains transect area $\mathrm{Ba}$, $\mathrm{Cu}, \mathrm{Pb}$, and $\mathrm{Zn}$ all appear to have two distributions, one being 
background, and the other a possible mineralization indicator. The predominant distributions of $\mathrm{Ba}, \mathrm{Pb}$, and $\mathrm{Zn}$ in samples reflect average crustal abundances (Krauskopf, 1979). However, sample 01JS012B (map no. 154) contained 1.3 percent $\mathrm{Ba}$ in an Fe-oxide-stained siliceous argillite near a gabbro sill. $\mathrm{Cu}$ background concentrations were found to be below average crustal levels, with a few exceptions. Two samples with noteworthy $\mathrm{Cu}$ concentrations were 01ANS023A and 99ARj020B1 (map nos. 181 and 142), which contained, respectively, 4.69 percent $\mathrm{Cu}$ from a $30-\mathrm{cm}$ thick silicified gossan at the contact of a mafic sill and sediments and 3.35 percent $\mathrm{Cu}$ from Nikolai greenstone with malachite stain. Three samples from east of Clark Creek, 00JS050H, K, and L (map nos. 88-90), contained the highest concentrations of $\mathrm{Pb}(367,1120$, and $1660 \mathrm{ppm}$, respectively) and $\mathrm{Zn}(597,2130$, and 18,900 ppm, respectively) in the area. All three samples were from an aplite with Feoxide staining or pyritic quartz veins.

Figure 4 shows histograms for the concentrations of arsenic (As), gold ( $\mathrm{Au})$, bismuth (Bi), and antimony (Sb), and figure 5 is a star-plot map showing the localities for which samples contained anomalous concentrations of those elements. These metals are also characteristically associated with hydrothermal mineralization. The analytical methods used for determining $\mathrm{Au}, \mathrm{Bi}$, and $\mathrm{Sb}$ have lower determination limits above the estimated average crustal abundances (Krauskopf, 1979). Therefore, the data for those elements are highly censored, with 155, 164, and 133 of 201 samples having concentrations below the determination limits for $\mathrm{Au}, \mathrm{Bi}$, and $\mathrm{Sb}$, respectively. Concentrations above $40 \mathrm{ppm} \mathrm{As}, 0.02 \mathrm{ppm}$ $\mathrm{Au}, 6 \mathrm{ppm} \mathrm{Bi}$, or $10 \mathrm{ppm} \mathrm{Sb}$ are considered to be anomalous. Three samples (02SC025C, D, and E; map nos. 115-117) from a quartz-kaolinite vein cross-cutting argillite and andesite dikes at the Mint Mine contained the three highest As values in the study area, as well as three of the highest concentrations of Au. Sample 02SC025E (map no. 117) contained $>6,000$ ppm As, 7.64 ppm Au, 2 ppm Bi, and 51 ppm Sb.

Figure 6 shows histograms for the distributions of silver $(\mathrm{Ag})$, mercury ( $\mathrm{Hg})$, lithium ( $\mathrm{Li})$, and molybdenum (Mo), and figure 7 is a star-plot map showing the localities for samples that contained anomalous concentrations of those elements. The lower determination limit for $\mathrm{Ag}$ is $0.08 \mathrm{ppm}$, which is near the crustal abundance level of $0.07 \mathrm{ppm}$ (Krauskopf, 1979). There are 76 samples with Ag below the lower determination limit. Ag values above $1.7 \mathrm{ppm}$ are considered anomalous in these data. The highest values for Ag were from samples from the Mint Mine (sample no. 02SC025E; map no. 117), from a quartz vein (sample no. 00ARj077B; map no. 192) cutting Nikolai greenstone, and from two samples (00JS050K and L; map nos. 88-89) from a pyritic quartz vein in aplite near Clark Creek. The lower determination limit for $\mathrm{Hg}(0.02 \mathrm{ppm})$ is well below the crustal abundance $(0.08$ ppm; Krauskopf, 1979). There were 150 samples that had Hg levels below the lower limit of determination, indicating either that background levels of $\mathrm{Hg}$ are low or that $\mathrm{Hg}$ is depleted in this area. Values greater than $0.26 \mathrm{ppm} \mathrm{Hg}$ are considered anomalous for these data. Li values are relatively consistent with crustal abundance estimates (Krauskopf, 1979); values greater than $80 \mathrm{ppm}$ are considered anomalous. Background concentrations for Mo in the sample data are relatively low; values exceeding $8 \mathrm{ppm}$ are considered anomalous.

Figure 8 shows histograms for the distributions of berillium (Be), manganese (Mn), titanium (Ti), and tungsten (W), and figure 10 shows histograms for the distributions of cobalt (Co), cromium (Cr), nickel (Ni), and vanadium (V). Figures 9 and 11 are star-plots maps showing the localities for which samples contained anomalous concentrations of the elements in figures 8 and 10, respectively. Lower determination limits for all these elements are well below crustal abundance levels, and concentrations in samples from the study area are relatively low compared to estimated crustal abundance (Krauskopf, 1979). Two samples have Be concentrations at or above 8 ppm; sample 02SC017B (map no. 40) is of a precipitate at a cold spring, and sample 00Arj048 (map no. 52 ) is from disseminated sulfides in the Kahiltna assemblage (Eastham and Ridgway, 2002). Four samples (00JS031B, 00JS050H, 00JS0050L, and 01JS039A; map nos. 149, 89, 88, and 108) have $\mathrm{Mn}$ concentrations at or above $2,700 \mathrm{ppm}$; three samples (01ANS026B, 02SC015A, and 02SC015B; map nos. 78, 66, and 67) have concentrations at or above 1.6 percent Ti; and five samples have $\mathrm{W}$ concentrations at or above $8 \mathrm{ppm}$. Three samples of basalts have Co concentrations above $100 \mathrm{ppm}$. Four samples, derived from gabbro, argillite, and Kahiltna mafic rocks, each contain concentrations greater than $160 \mathrm{ppm}$ Cr. Three samples had analytical results greater than $140 \mathrm{ppm}$ $\mathrm{Ni}$, and two samples had greater than $450 \mathrm{ppm} \mathrm{V}$.

Figures 12 and 13 show histograms and star plots, respectively, for the distribution of cerium (Ce), europium (Eu), niodymium (Nd), and yttrium (Y). Concentrations at or greater than $400 \mathrm{ppm} \mathrm{Ce}, 8 \mathrm{ppm} \mathrm{Eu}, 70 \mathrm{ppm} \mathrm{Nd}$, or $70 \mathrm{ppm}$ Y were considered to be anomalous for this area. The highest concentrations for each of these elements were in three samples from a cold spring precipitate. These samples $(02 \mathrm{SC} 017 \mathrm{~A}-\mathrm{C}$; map nos. 39-41) contained concentrations of 759, 1,010, and 2,710 ppm Ce; 89, 141, and $281 \mathrm{ppm} \mathrm{Eu;} \mathrm{713,} \mathrm{1,150,} \mathrm{and} \mathrm{2,230} \mathrm{ppm}$ $\mathrm{Nd}$; and 1,040, 1,410, and 4,170 ppm Y. Additionally, these three samples also contained $0.7-0.8 \mathrm{ppm} \mathrm{Au}, 5-10 \mathrm{ppm} \mathrm{Be}$, 4-13 ppm Bi, 12-31 percent Fe, 800-3,200 ppm Zn, and as much as $3,500 \mathrm{ppm} \mathrm{Ba}$.

\section{Discussion}

Several samples from localities within the Talkeetna Mountains transect contain anomalous concentrations of a wide range of elements, which are suggestive of the potential for mineral occurrences. Samples from the Mint Mine (02SC025C-J; map nos. 115-121) contained anomalous concentrations of $\mathrm{Ag}, \mathrm{As}$, and $\mathrm{Au}$ with minor $\mathrm{Bi}, \mathrm{Li}$, and $\mathrm{Sb}$ (table 1). Although chalcopyrite $(\mathrm{CuFeS})$ and tennantite (CuFeAsS) are reported to occur at the Mint Mine (Rogers and Schmidt, 
2003), elevated values for $\mathrm{Cu}$ were not observed in analyses of the samples from the mine.

Three samples, 00JS050H-L (map nos. 88-90), of sulfidebearing quartz vein in aplite at the Clark Bar prospect east of Clark Creek $\left(63.0^{\circ} \mathrm{N}, 148.7^{\circ} \mathrm{W}\right)$ contained anomalously high concentrations of $\mathrm{Ag}, \mathrm{Ba}, \mathrm{Bi}, \mathrm{Cd}, \mathrm{Cu}, \mathrm{Li}, \mathrm{Mn}, \mathrm{Mo}, \mathrm{Pb}$, and $\mathrm{Zn}$ (Schmidt and Gamble, 2003).

Samples 02SC017A-D (map nos. 39-42) of precipitate from a bubbling cold spring south of Honolulu Pass near Thoroughfare Creek, contained 0.7 to $0.8 \mathrm{ppm} \mathrm{Au}, 4$ to $18 \mathrm{ppm}$ $\mathrm{Bi}, 12$ to 50 percent $\mathrm{Fe}, 803$ to $3,190 \mathrm{ppm} \mathrm{Zn}$, and as much as 10 ppm Be, 2,710 ppm Ce, 281 ppm Eu, 1,210 La, 2,230 Nd, $4,170 \mathrm{Y}$, and $334 \mathrm{Yb}$.

\section{Ackowledgments}

Samples for this study were collected by USGS geologists Charles "Skip" Cunningham, Bruce Gamble, Steve Nelson, J.M. O'Niell, Jim Riehel, and Jeanine Schmidt and by contractor Bob Rogers. We thank helicopter pilots Gary Brogdon (Maritime Helicopters, 1999), Bill Merkley (Transalaska and Evergreen Helicopters, 2000-2001) and Dave Beard (Prism Helicopters, 2002) for their patience and skill and for finding landing zones in the most unlikely places. Theresa Taylor and Nora Shew provided valuable help in preparing figures from GIS datasets. Reviews by Bruce Gamble and Greg Lee helped improve an earlier version of the manuscript.

\section{References Cited}

Balen, M.D., 1990, Geochemical sampling results from Bureau of Mines investigations in the Valdez Creek mining district, Alaska: U.S. Bureau of Mines Open-File Report 34-90, $250 \mathrm{p}$.

Briggs, P.H., 2002, The determination of forty elements in geological and botanical samples by inductively coupled plasma-atomic absorption spectrometry, chap. G of Taggart, J.E., Jr., ed., Analytical methods for chemical analysis of geologic and other materials, U.S. Geological Survey: U.S. Geological Survey Open-File Report 02-0223 [http:// pubs.usgs.gov/of/2002/ofr-02-0223/, last accessed on March 11, 2009].

Brown, Z.A., O'Leary, R.M., Hageman, P.L., and Crock, J.G., 2002, Mercury in water, geologic, and plant materials by continuous flow-cold vapor-atomic absorption spectrometry, chap. M of Taggart, J.E., Jr., ed., Analytical methods for chemical analysis of geologic and other materials, U.S. Geological Survey: U.S. Geological Survey Open-File Report 02-0223 [http://pubs.usgs.gov/of/2002/ofr-02-0223/, last accessed on December 23, 2009].
Csejtey, Bela, Jr., Mullen, M.W., Cox, D.P., and Stricker, G.D., 1992, Geology and geochronology of the Healy quadrangle, south-central Alaska: U.S. Geological Survey Miscellaneous Investigations Series Map I-1961, 63 p., 2 maps, scale 1:250,000.

Csejtey, Bela, Jr., Nelson, W.H., Jones, D.L., Silberling, N.J., Dean, R.M., Morris, M.S., Lanphere, M.A., Smith, J.G., and Silberman, J.L., 1978, Reconnaissance geologic map and geochronology, Talkeetna Mountains quadrangle, northern part of Anchorage quadrangle, and southwest corner of Healy quadrangle, Alaska: U.S. Geological Survey OpenFile Report 78-558-A, 62 p., 1 map, scale 1:250,000.

Detra, D.E., 2006, Analytical contract laboratory method summaries and costs: [http://minerals.cr.usgs.gov/intranet/chem/ labmethods.html, last accessed on March 5, 2009].

Eastham, K.R., and Ridgway, K.D., 2002, Stratigraphic and provenance data from the Upper Jurassic-Upper Cretaceous Kahiltna assemblage of south-central Alaska, in Wilson, F.H., and Galloway, J.P., eds., Studies in Alaska by the U.S. Geological Survey during 2000: U.S. Geological Survey Professional Paper 1662, p. 45-53.

Glen, J.M.G., McPhee, D.K., Schmidt, J.M., Pellerin, Louise, and Morin, R.L., 2003, Terrane-scale crustal structures of south-central Alaska inferred from regional geophysical studies [abs.]: Geological Society of America Abstracts with Programs, v. 35 , no. 6, p. 560.

Glen, J.M.G., Schmidt, J.M., Pellerin, Louise, McPhee, D.K., and O'Neill, J.M., 2007, Crustal structure of Wrangellia and adjacent terranes inferred from geophysical studies along a transect through the northern Talkeetna Mountains, in Ridgeway, K.D., Trop, J.M., Glen, J.M.G., and O'Neill, J.M., eds., Tectonic growth of a collisional continental margin; crustal evolution of southern Alaska: Geological Society of American Special Paper 431, p. 21-42.

Hampton, B.A., Ridgway, K.D., O’Neill, J.M., Blodgett, R.B., and Gutenkunst, M.L., 2003, Stratigraphy, provenance, and tectonic significance of newly-defined Mesozoic strata in the Northwestern Talkeetna Mountains [abs.]: Geological Society of America Abstracts with Programs, v. 35, no. 6, p. 559-560.

Hampton, B.A., Ridgway, K.D., O’Neill, J.M., Gehrels, G.E., Schmidt, J.M., and Blodgett, R.B., 2007, Pre-, syn-, and post-collisional stratigraphic framework and provenance of Upper Triassic-Upper Cretaceous strata in the northwestern Talkeetna Mountains, Alaska, in Ridgway, K.D., Trop, J.M., O’Neill, J.M., and Glen, J.M.G., eds., Tectonic growth of a collisional continental margin; crustal evolution of southern Alaska: Geological Society of America Special Paper 431, p. 401-438. 
King, H.D., Light, T.D., and O'Leary, R.M., 1989, Maps showing distribution and abundance of selected elements in stream-sediment samples from a reconnaissance geochemical survey of the Healy quadrangle, Alaska: U.S. Geological Survey Miscellaneous Field Studies Map MF-2058-B, scale 1:250,000.

Krauskopf, K.B., 1979, Introduction to Geochemistry (2d ed): New York, McGraw Hill, 617 p.

Light, T.D., King, H.D., and Sutley, S.J., 1989a, Maps showing distribution and abundance of selected elements in heavy-mineral-concentrate samples from a reconnaissance geochemical survey of the Healy quadrangle, Alaska: U.S. Geological Survey Miscellaneous Field Studies Map MF2058-C, scale 1:250,000.

Light, T.D., Tripp, R.B., and King, H.D., 1989b, Interpretation of reconnaissance geochemical data from the Healy quadrangle, Alaska: U.S. Geological Survey Bulletin 1894, 36 p.

Nokleberg, W.J., Plafker, George, and Wilson, F.H., 1994, Geology of south-central Alaska, chap. 10 of Plafker, George, and Berg, H.C., eds., The geology of Alaska: Boulder, Colo., Geological Society of America, The geology of North America, v. G-1, p. 311-366.

O'Neill, J.M., Schmidt, J.M., Glen, J.M.G., and Pellerin, Louise, 2003, Mesozoic and Tertiary structural history of the northern Talkeetna Mountains [abs.]: Geological Society of America Abstracts with Programs, v. 35, no. 6, p. 560.
Rogers, R.K, and Schmidt, J.M., 2003, Alaska resource data file; Talkeetna Mountains quadrangle: U.S. Geological Survey Open-File Report 03-457, 260 p. [http://ardf.wr.usgs. gov/ardf_data/TalkeetnaMountains.pdf, last accessed on March 11, 2009].

Schmidt, J.M., and Gamble, B.M., 2003, The Clark Bar prospect; granite-hosted Sn-Mo-Ag mineralization in the northern Talkeetna Mountains, in Galloway, J.P., ed., Studies by the U.S. Geological Survey in Alaska, 2001: U.S. Geological Survey Professional Paper 1678, p. 93-104.

Schmidt, J.M., O’Neill, J.M., Snee, L.W., Blodgett, R.B., Ridgway, K.D., Wardlaw, B.R., and Blome, C.D., 2003, The northwestern edge of Wrangellia; stratigraphic and intrusive links between crustal blocks from the Peninsular terrane to Broad Pass [abs.]: Geological Society of America Abstracts with Programs, v. 35, no. 6, p. 560-561.

Schmidt, J.M., and Rogers, R.K., 2007, Metallogeny of the Nikolai large igneous province (LIP) in southern Alaska and its influence on the mineral potential of the Talkeetna Mountains, in Ridgway, K.D., Trop, J.M., Glen, J.M.G., and O'Neill, J.M., eds., Tectonic growth of a collisional continental margin; crustal evolution of southern Alaska: Geological Society of America Special Paper 431, p. 623-648.

Stevens, D.L., 2001, Alaska resource data file; Healy quadrangle: U.S. Geological Survey Open-File Report 01-109, 441 p. [http://ardf.wr.usgs.gov/ardf_data/Healy.pdf, last accessed on March 11, 2009]. 
Figures 2-13 


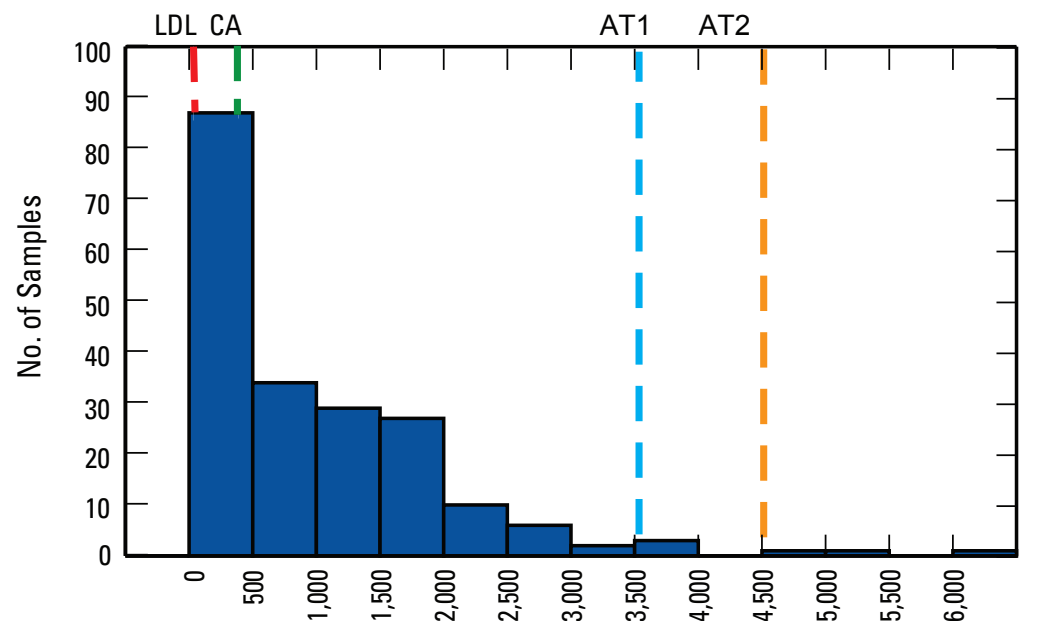

$\mathrm{Ba}(\mathrm{ICP} 40), \mathrm{ppm}$

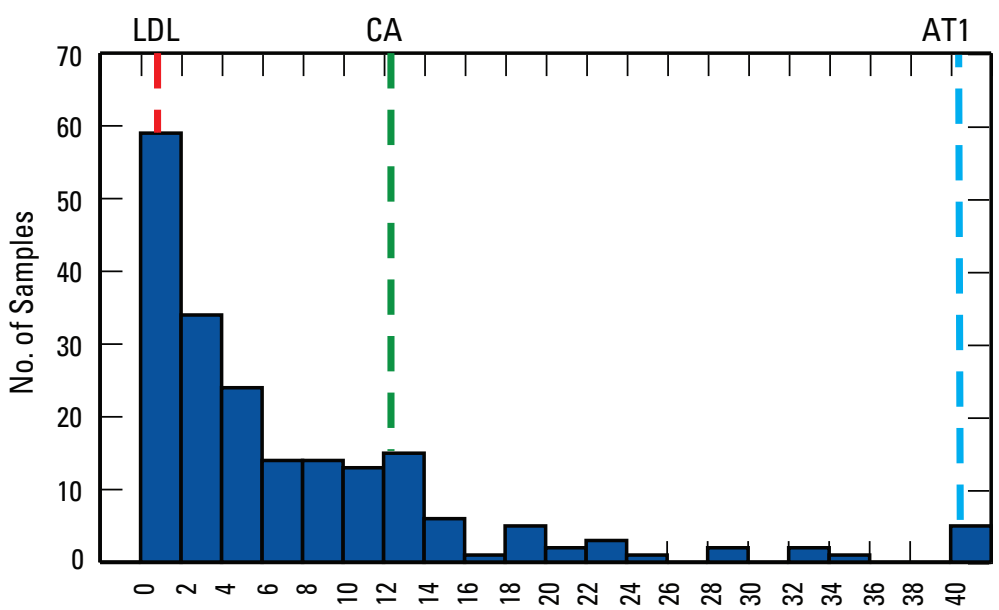

$\mathrm{Pb}(\mathrm{ICP} 10), \mathrm{ppm}$
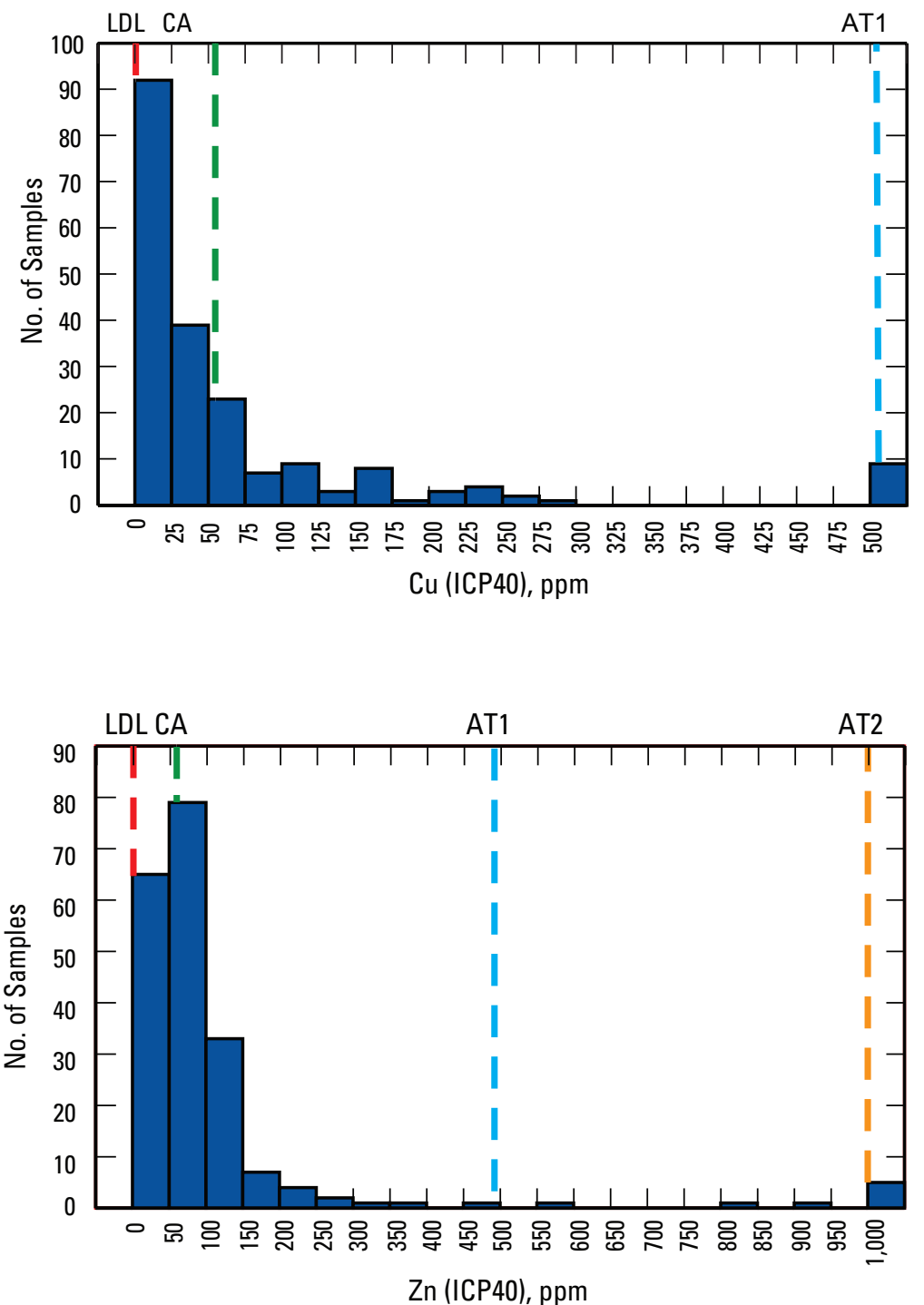

Figure 2. Histograms showing distribution of $\mathrm{Ba}, \mathrm{Cu}, \mathrm{Pb}$, and $\mathrm{Zn}$ in samples from the northern Talkeetna Mountains. $\mathrm{CA}=$ crustal abundance (Krauskopf, 1979); $\mathrm{LDL}=$ lower detection limit; $\mathrm{AT} 1=$ lower anomalous threshold; $\mathrm{AT} 2=$ upper anomalous threshold; ICP40= 40-element inductively coupled plasma atomic-emission spectrometry; ICP10 = 10-element inductively coupled plasma atomic-emission spectrometry; ppm= parts per million. 


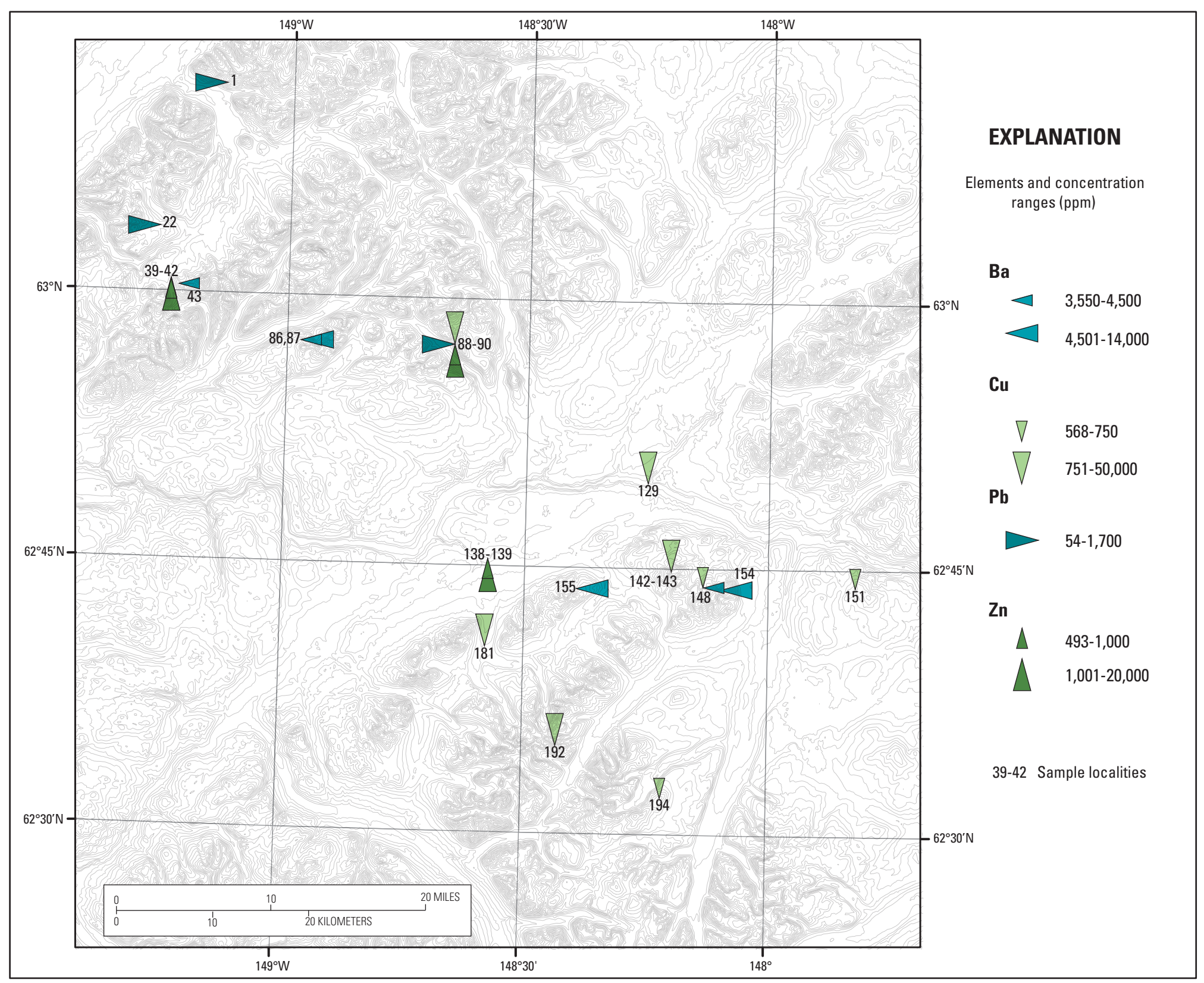

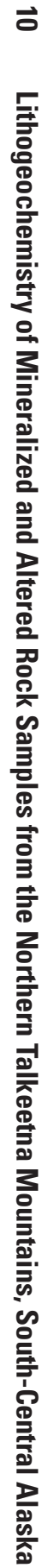

Figure 3. Star-plot map showing localities for samples containing high concentrations of $\mathrm{Ba}, \mathrm{Cu}, \mathrm{Pb}$, and $\mathrm{Zn}$. 


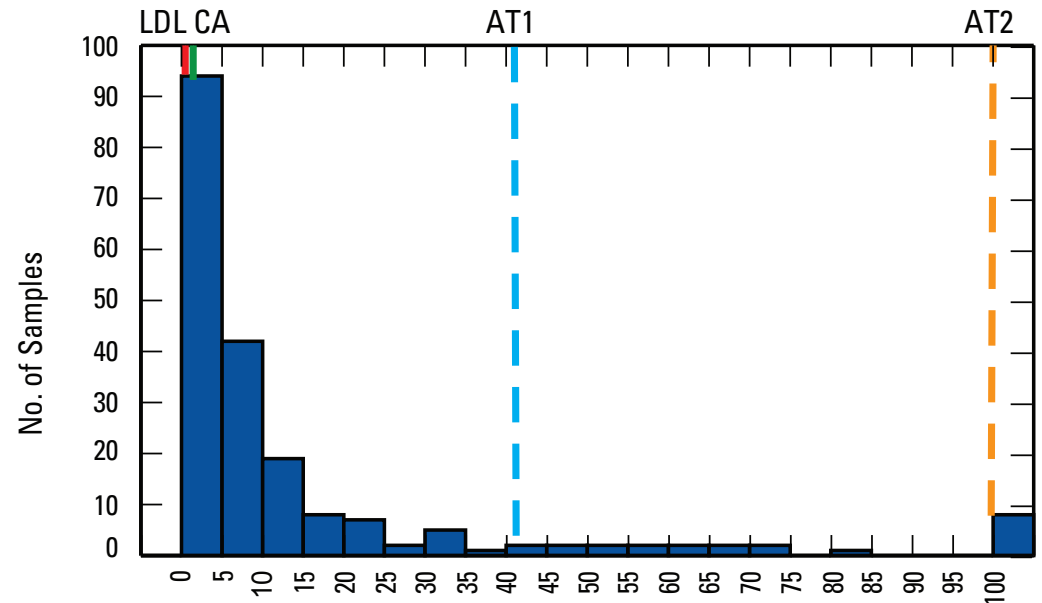

As (ICP10), ppm

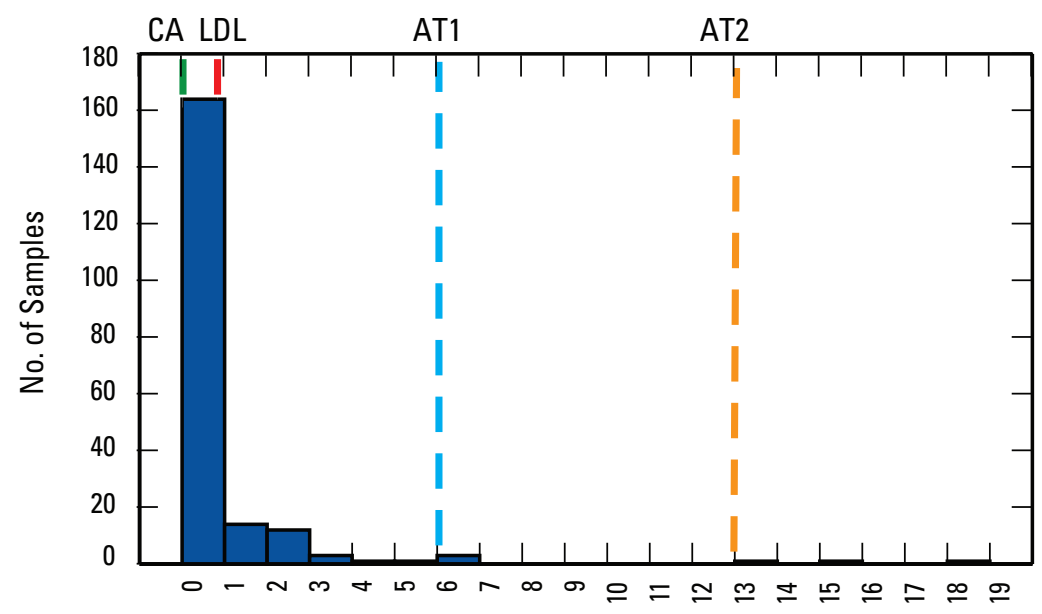

Bi (ICP10), ppm

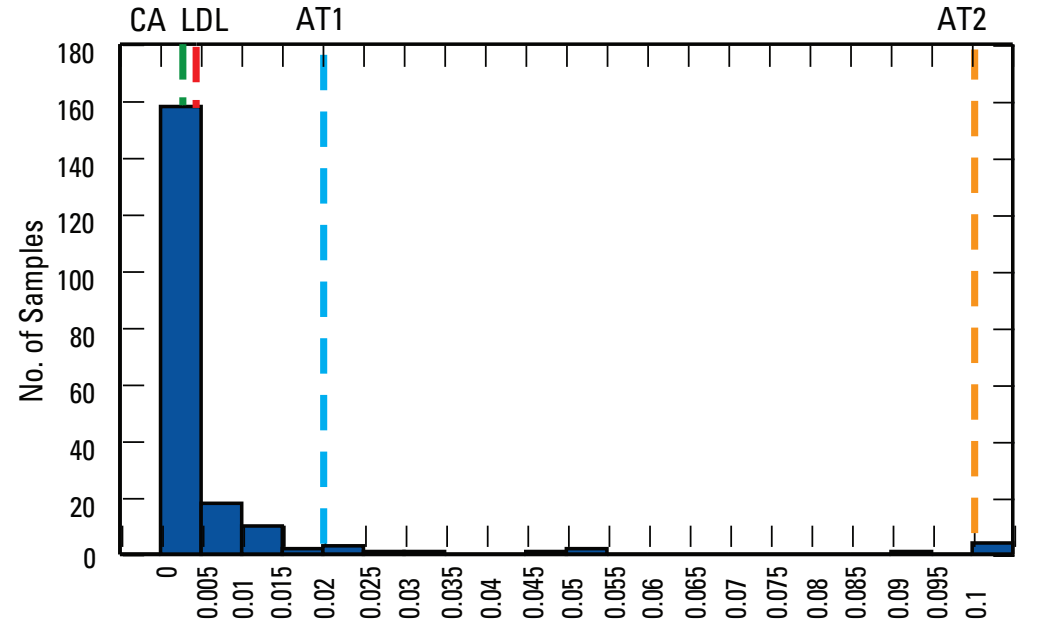

$\mathrm{Au}(\mathrm{FA}), \mathrm{ppm}$

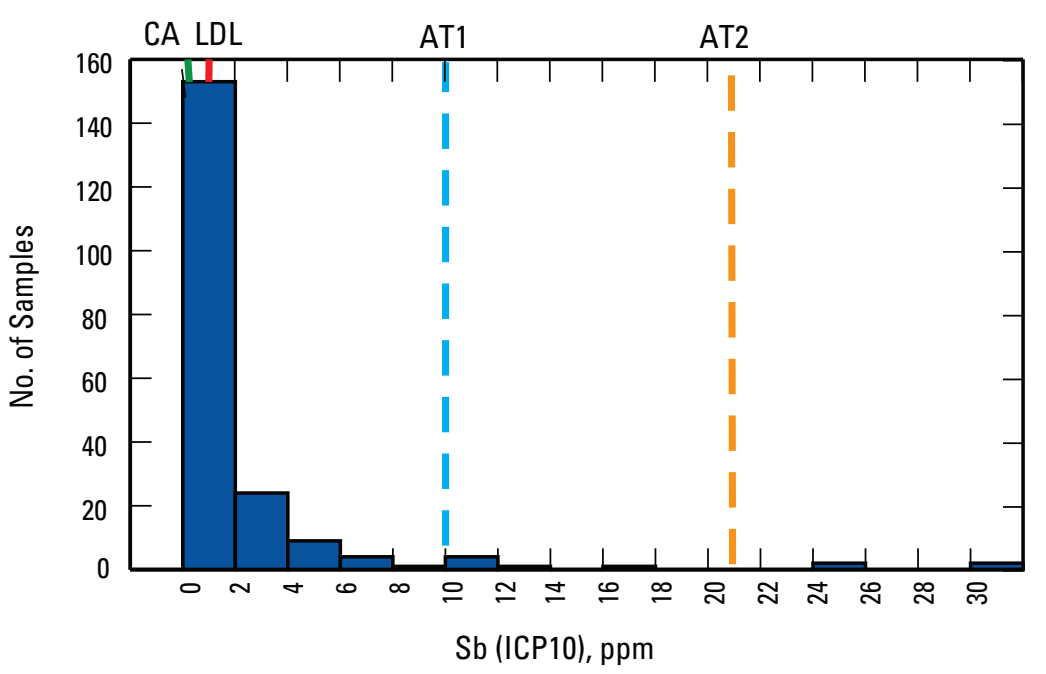

Figure 4. Histograms showing distribution of $\mathrm{As}, \mathrm{Au}, \mathrm{Bi}$, and $\mathrm{Sb}$ in samples from the northern Talkeetna Mountains. $\mathrm{CA}=\mathrm{crustal}$ abundance (Krauskopf, 1979); $\mathrm{LDL}=$ lower detection limit; $A T 1=$ lower anomalous threshold; $A T 2=$ upper anomalous threshold; ICP10=10-element inductively coupled plasma atomic-emission spectrometry; $F A=$ fire assay; $p p m=$ parts per million. 


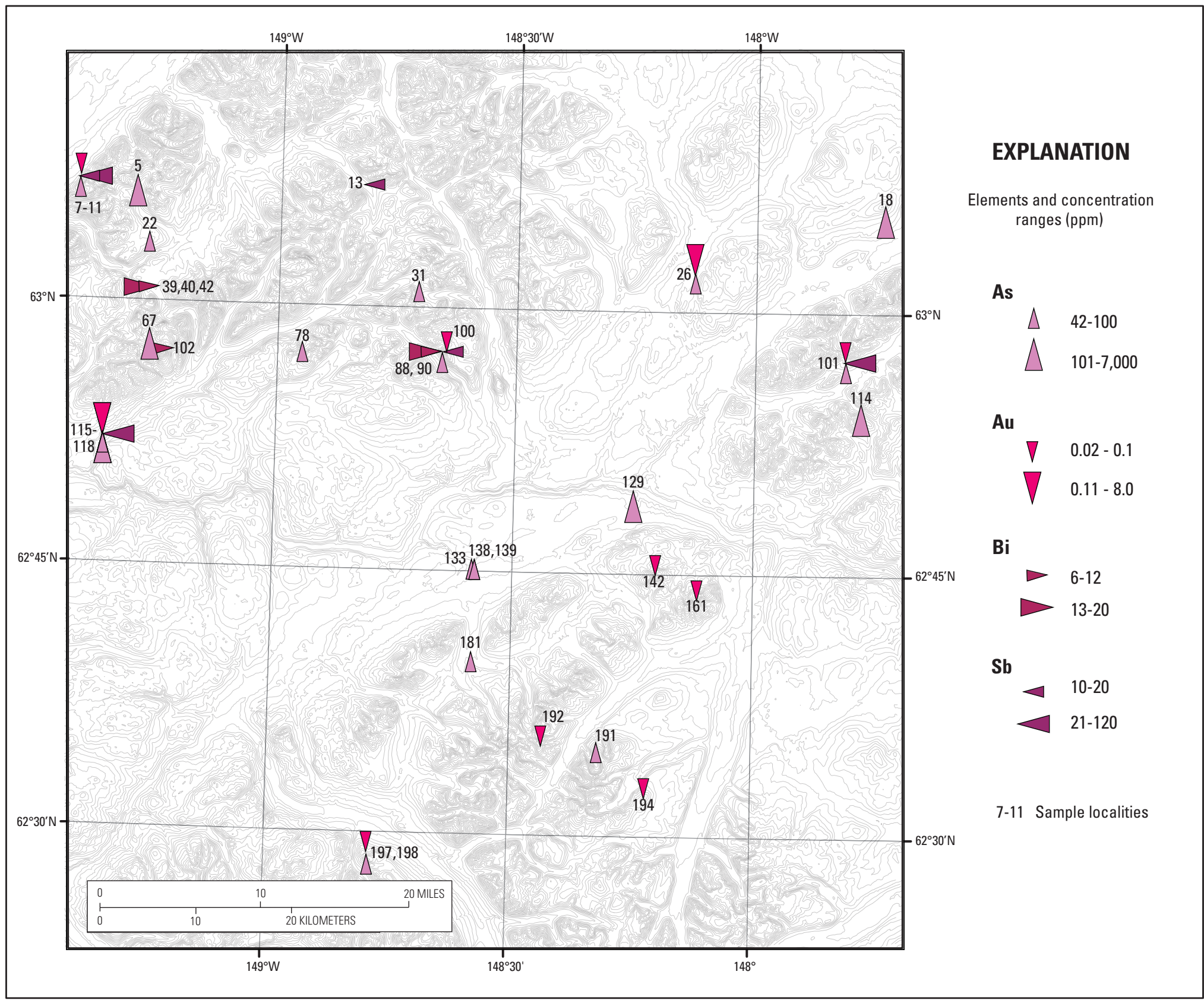

Figure 5. Star-plot map showing localities for samples containing high concentrations $\mathrm{As}, \mathrm{Au}, \mathrm{Bi}$, and $\mathrm{Sb}$. 

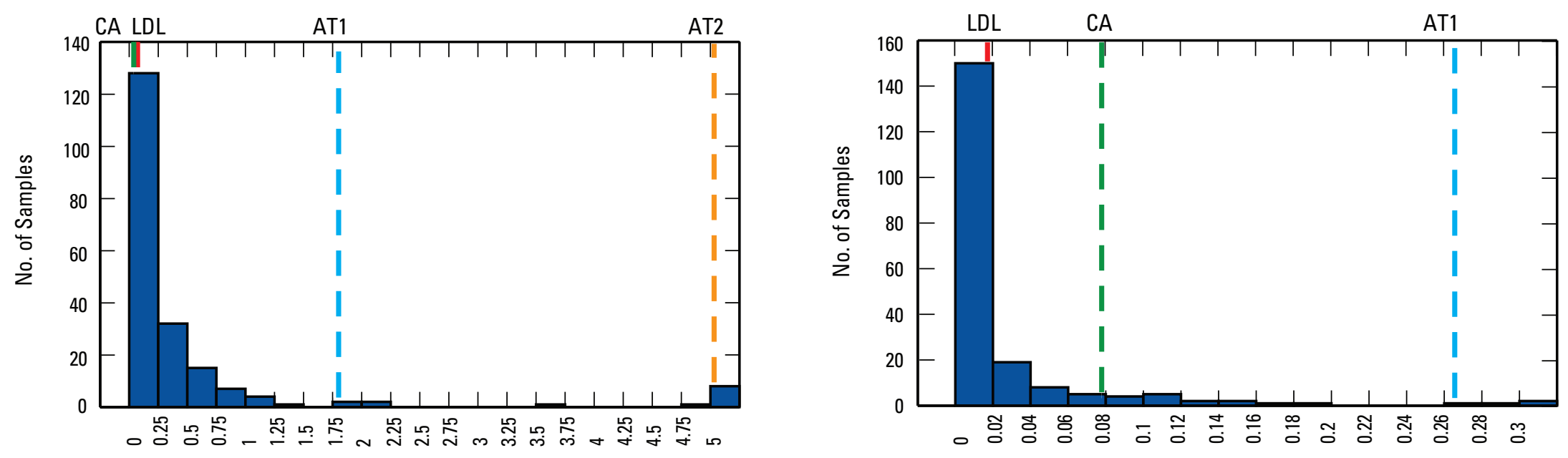

$\mathrm{Ag}$ (ICP10), ppm
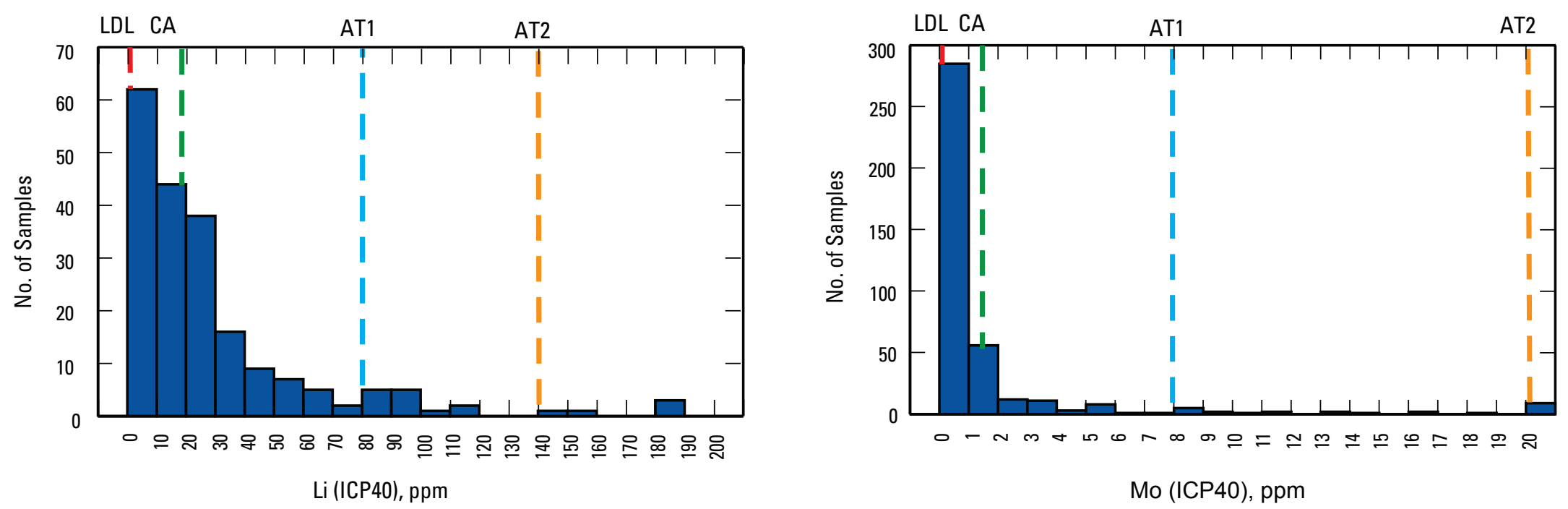

Mo (ICP40), ppm

Figure 6. Histograms showing distribution of $\mathrm{Ag}, \mathrm{Hg}$, $\mathrm{Li}$, and $\mathrm{Mo}$ in samples from the northern Talkeetna Mountains. $\mathrm{CA}=$ crustal abundance (Krauskopf, 1979); $\mathrm{LDL}=$ lower detection limit; $\mathrm{AT} 1=$ lower anomalous threshold; $A T 2=$ upper anomalous threshold; ICP40= 40-element inductively coupled plasma atomic-emission spectrometry; ICP10 = 10-element inductively coupled plasma atomic-emission spectrometry; $C V A A=$ cold vapor atomic absorption; ppm= parts per million. 


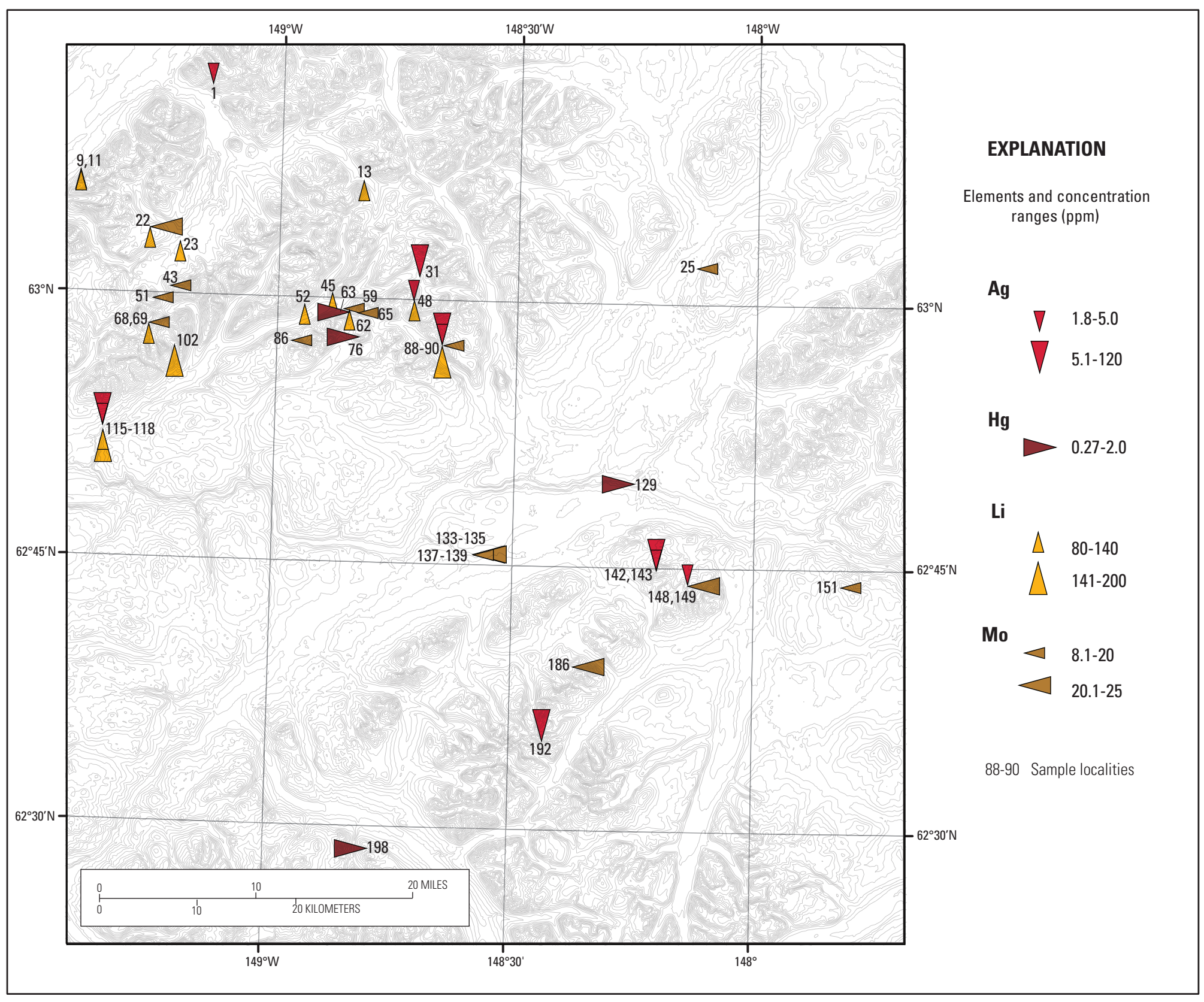

Figure 7. Star-plot map showing localities for samples containing high concentrations $\mathrm{Ag}, \mathrm{Hg}$, Li, and $\mathrm{Mo}$. 

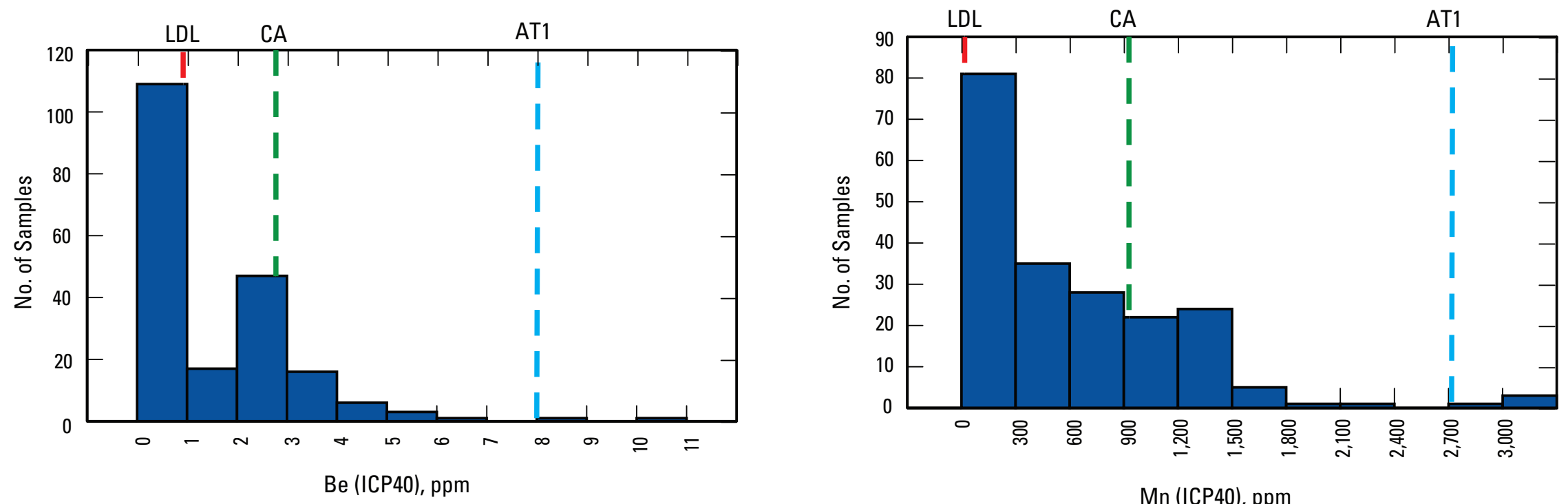

$\mathrm{Mn}(\mathrm{ICP} 40), \mathrm{ppm}$

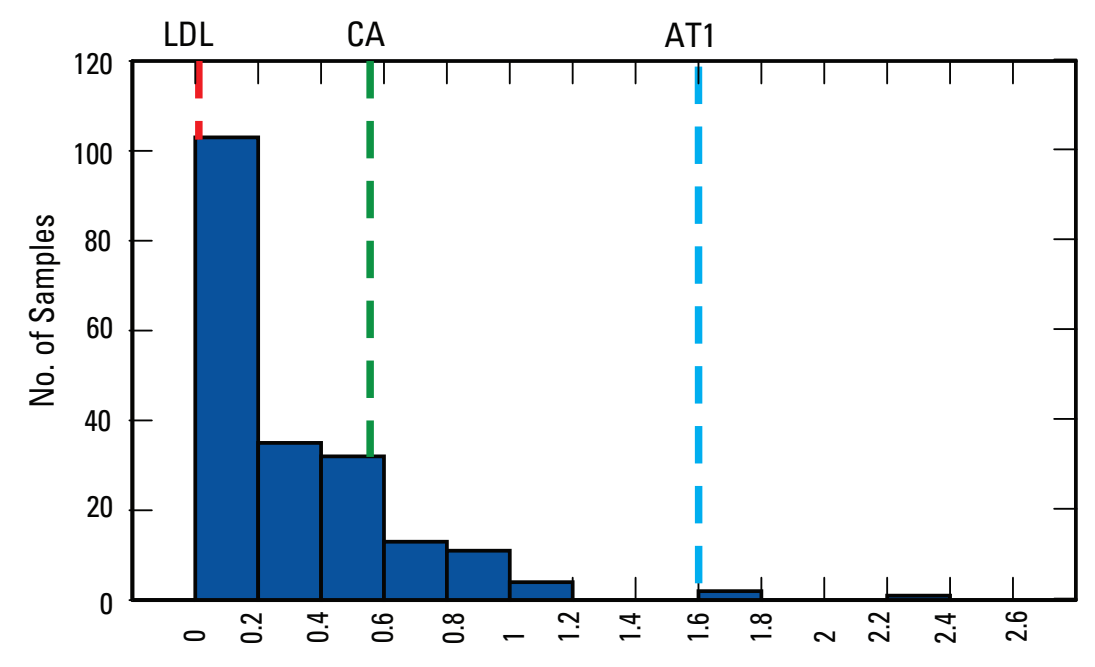

Ti (ICP40), percent

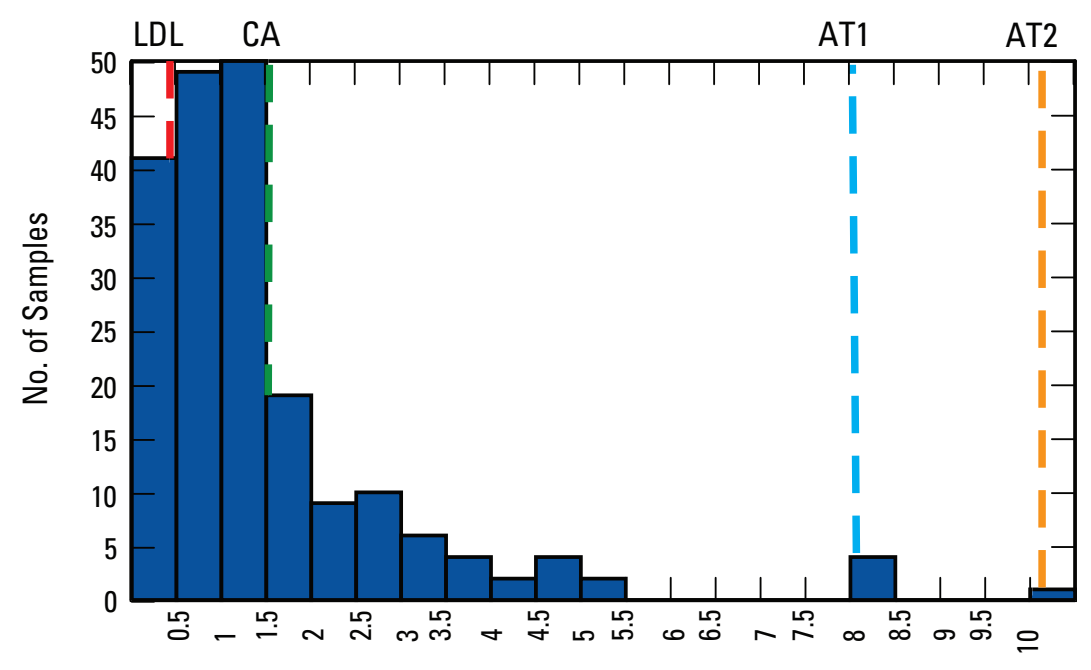

W (INAA), ppm

Figure 8. Histograms showing distribution of $\mathrm{Be}, \mathrm{Mn}, \mathrm{Ti}$, and $\mathrm{W}$ in samples from the northern Talkeetna Mountains. $\mathrm{CA}=$ crustal abundance (Krauskopf, 1979); $\mathrm{LDL}=\mathrm{lower}$ detection limit; AT1= lower anomalous threshold; AT2= upper anomalous threshold; ICP40= 40-element inductively coupled plasma atomic-emission spectrometry; INAA= irradiated neutron activation analysis; $\mathrm{ppm}=$ parts per million. 


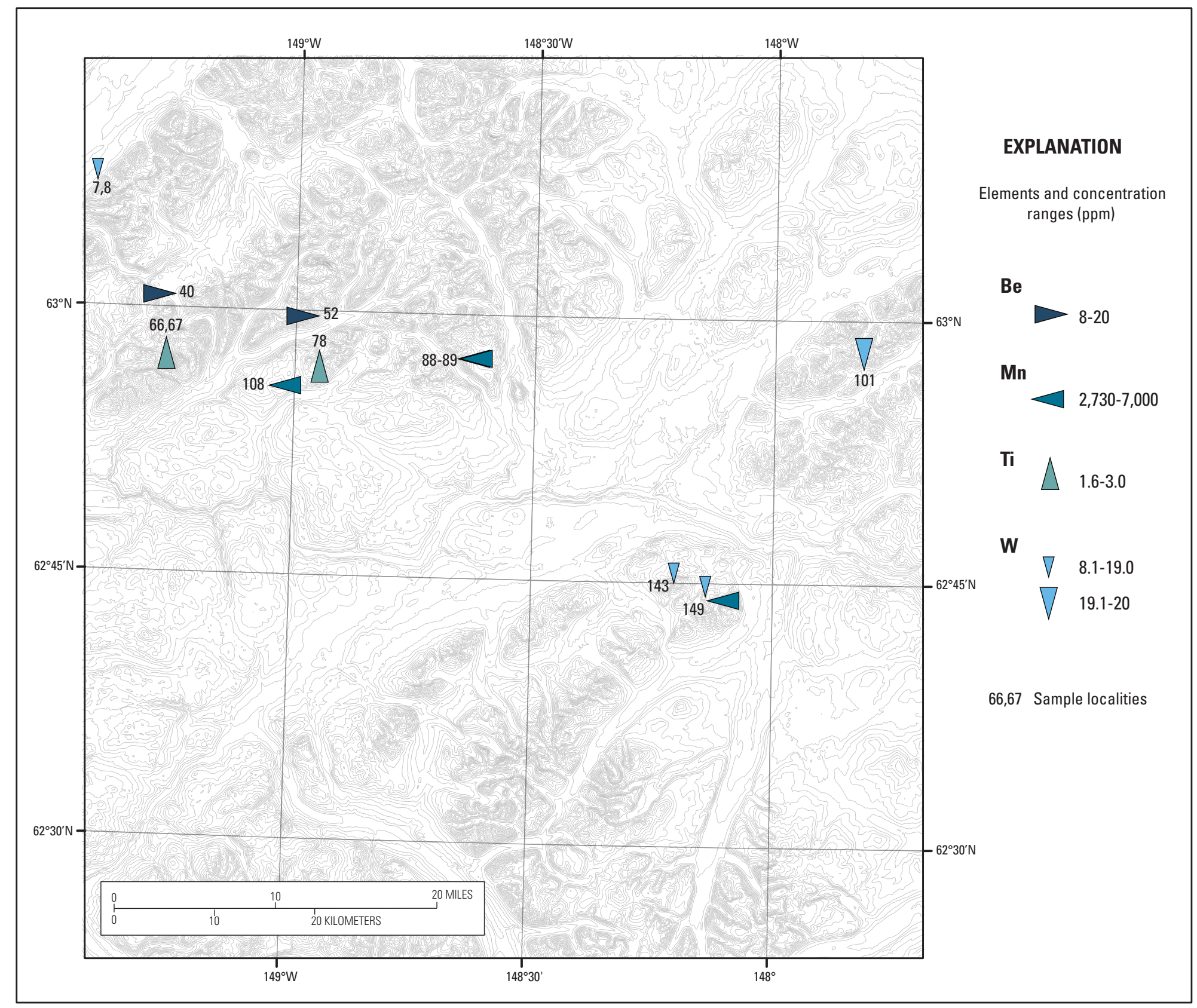

Figure 9. Star-plot map showing localities for samples containing high concentrations $\mathrm{Be}, \mathrm{Mn}, \mathrm{Ti}$, and $\mathrm{W}$. 

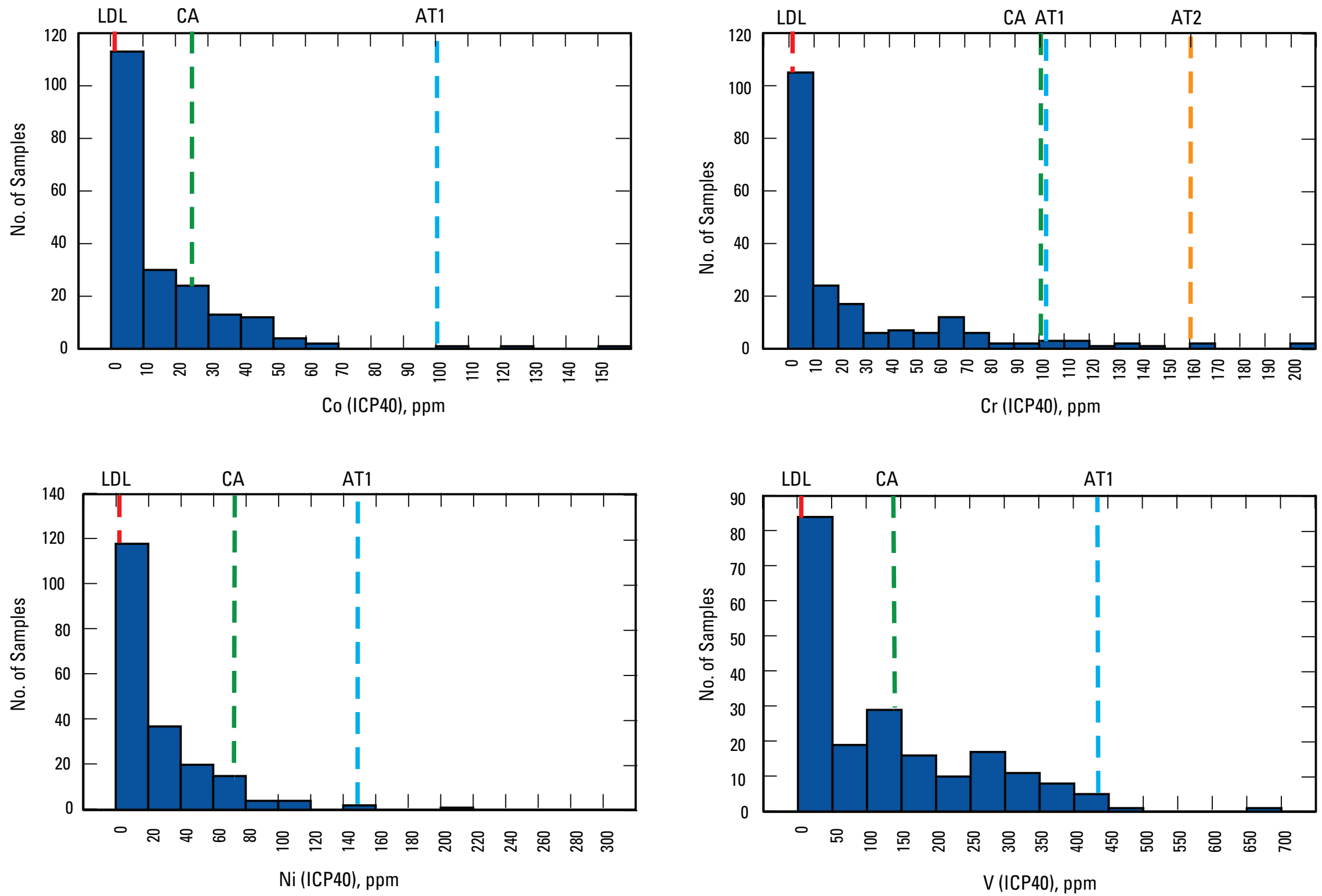

Figure 10. Histograms showing distribution of $\mathrm{Co}, \mathrm{Cr}, \mathrm{Ni}$, and $\mathrm{V}$ in samples from the northern Talkeetna Mountains. CA = crustal abundance (Krauskopf, 1979); LDL = lower detection limit; $A T 1=$ lower anomalous threshold; $A T 2=$ upper anomalous threshold; ICP40=40-element inductively coupled plasma atomic-emission spectrometry; ppm= parts per million. 


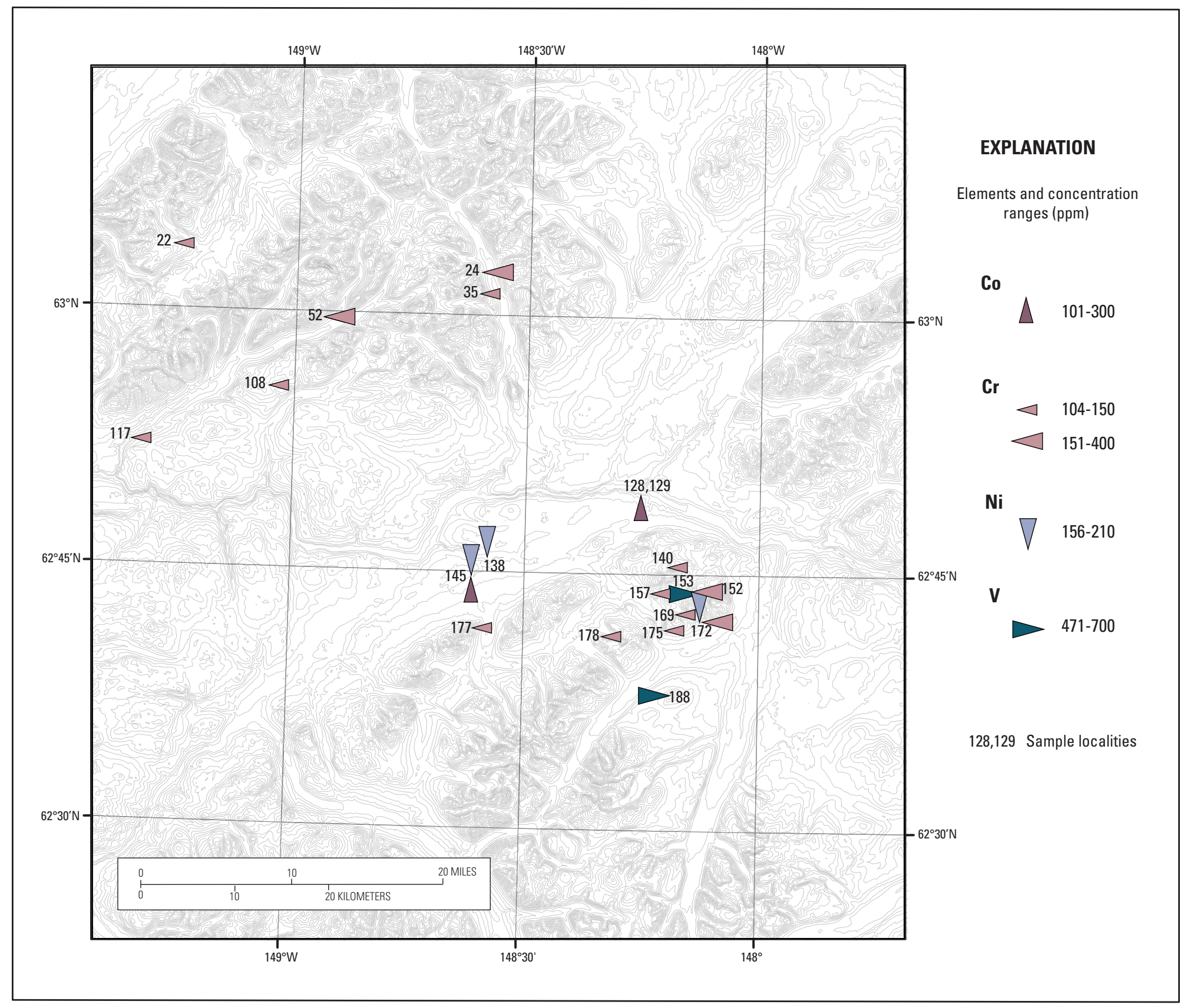

Figure 11. Star-plot map showing localities for samples containing high concentrations $\mathrm{Co}, \mathrm{Cr}$, $\mathrm{Ni}$, and $\mathrm{V}$. 


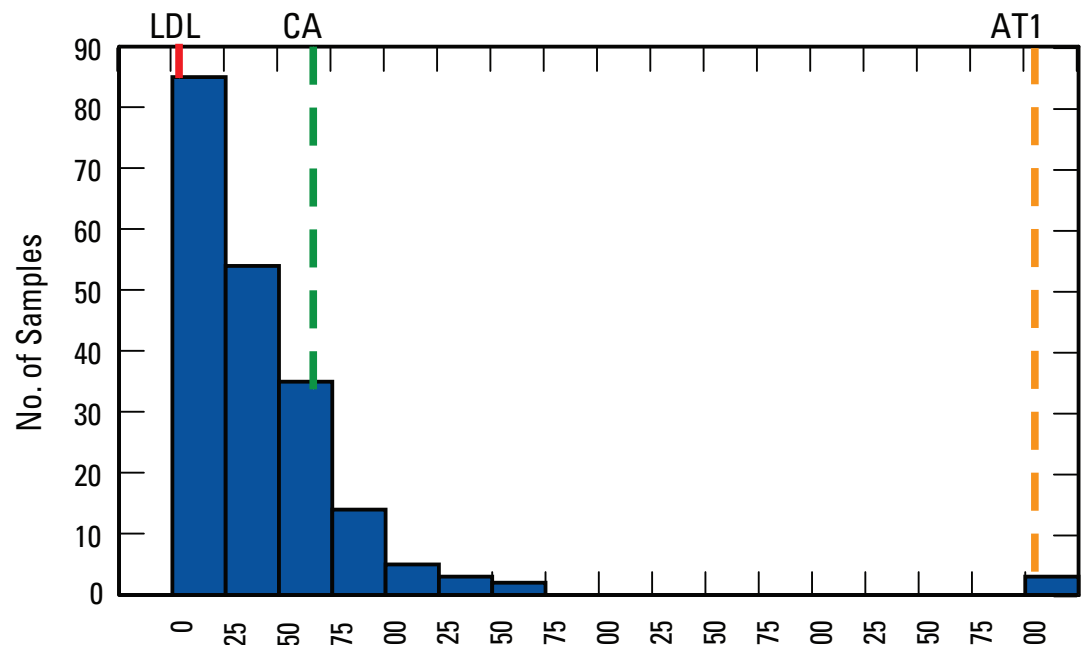

Ce (ICP40), ppm

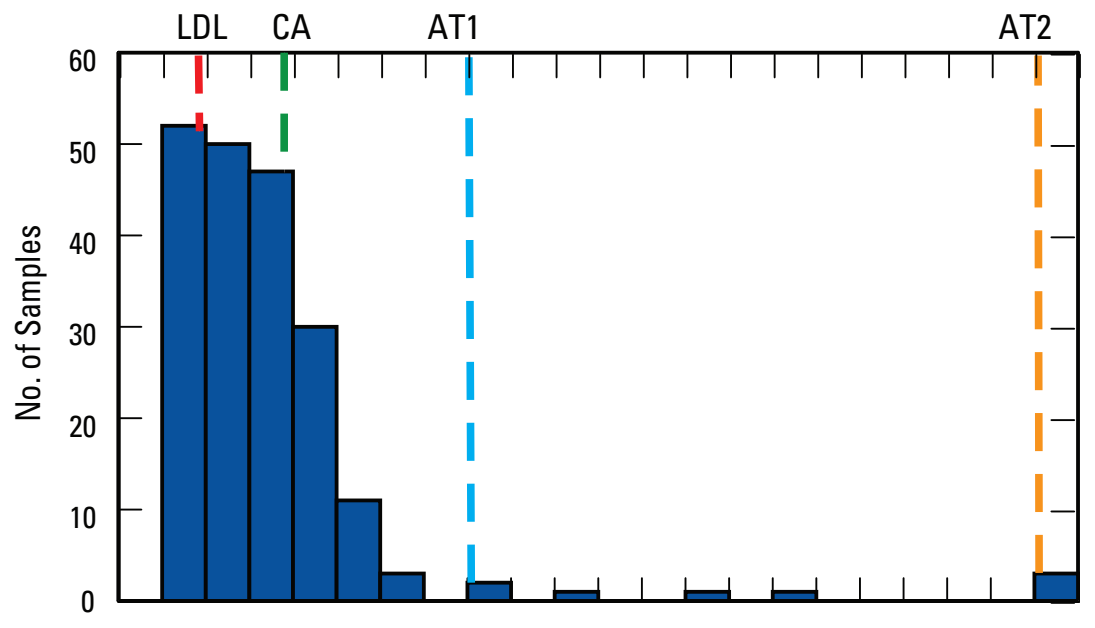

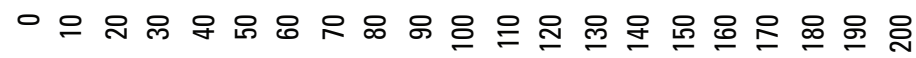

$\mathrm{Nd}(\mathrm{ICP} 40), \mathrm{ppm}$

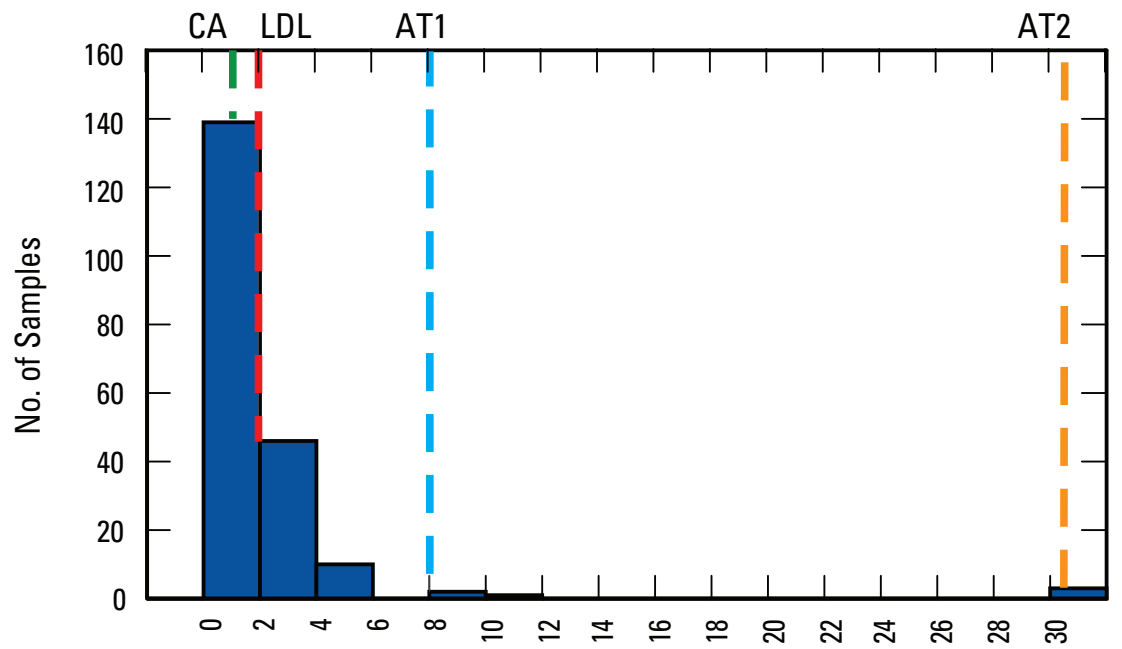

Eu (ICP40), ppm

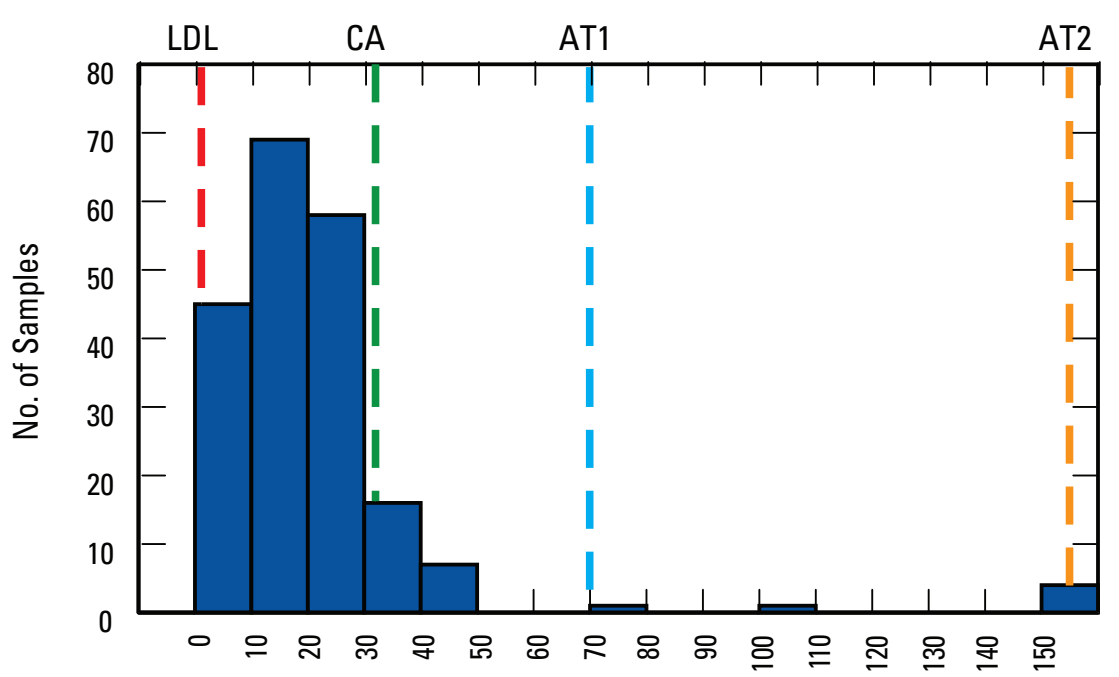

Y (ICP40), ppm

Figure 12. Histograms showing distribution of $\mathrm{Ce}, \mathrm{Eu}, \mathrm{Nd}, \mathrm{Y}$ in samples from the northern Talkeetna Mountains. $\mathrm{CA}=\mathrm{crustal}$ abundance (Krauskopf, 1979); $\mathrm{LDL}$ = lower detection limit; AT1= lower anomalous threshold; AT2= upper anomalous threshold; ICP40= 40-element inductively coupled plasma atomic-emission spectrometry; ppm= parts per million. 


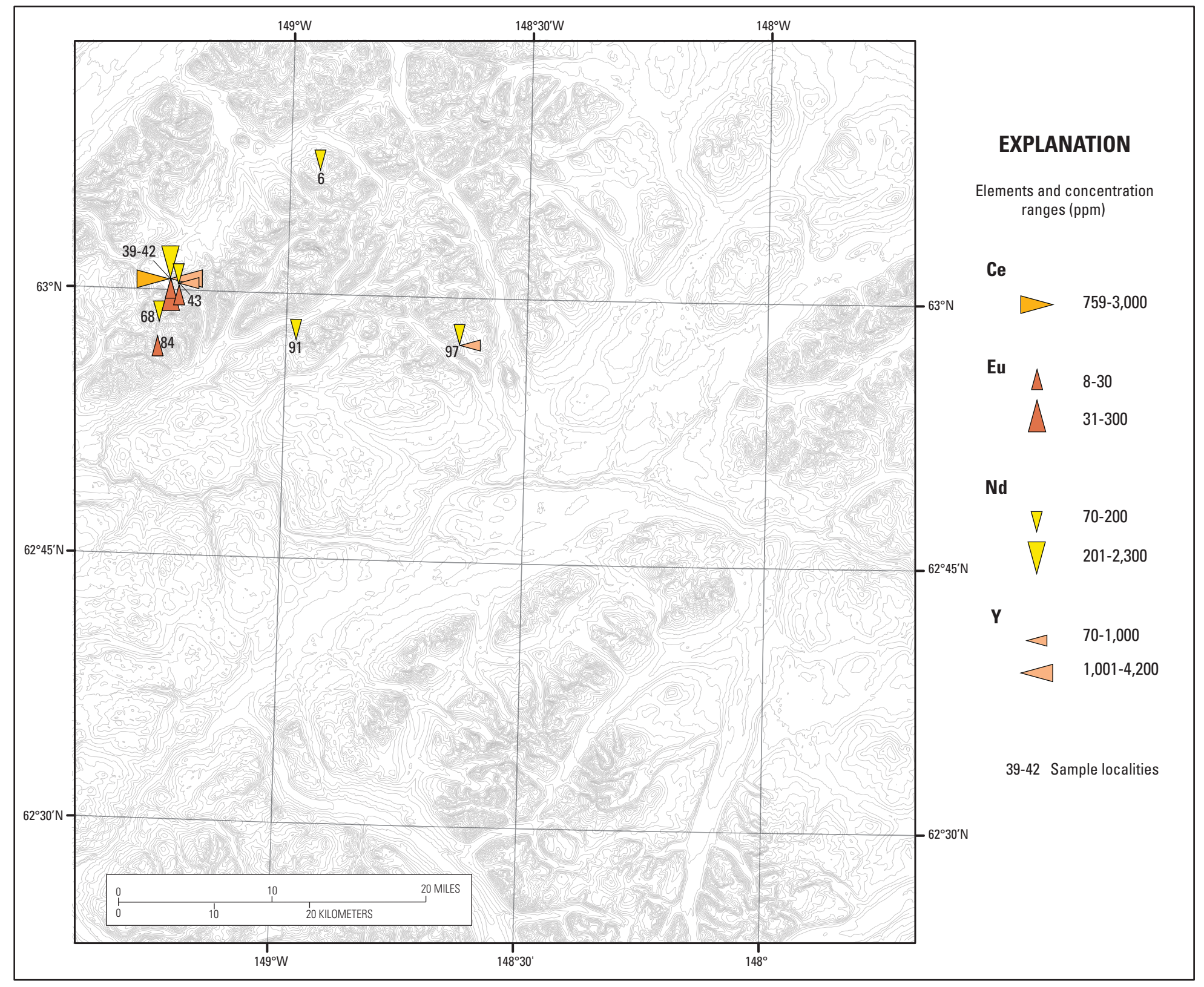

Figure 13. Star-plot map showing localities for samples containing high concentrations $\mathrm{Ce}, \mathrm{Eu}, \mathrm{Nd}$, and $\mathrm{Y}$. 

Tables 2-3 
Table 2. Analytical data for quality-control samples from the northern Talkeetna Mountains, Alaska.

[Analytical methods: 1, 10-element ICP-AES DIBK extraction; 2, 40-element ICP-AES total extraction; 3, fire assay-DCP-AES; 4, CVAA; 5, INAA]

\begin{tabular}{|c|c|c|c|c|c|c|c|c|c|c|c|c|c|c|c|c|c|c|c|}
\hline Field No. & $\begin{array}{l}\text { Latitude } \\
\text { (Deg. N) }\end{array}$ & $\begin{array}{c}\text { Longitude } \\
\text { (Deg. W) }\end{array}$ & $\begin{array}{r}\text { Element - } \\
\text { Sample Description } \\
\text { Analytical Method } 1 \text { - } \\
\text { Units - }\end{array}$ & $\begin{array}{c}\mathrm{Ag} \\
1 \\
\mathrm{ppm}\end{array}$ & $\begin{array}{l}\text { Al } \\
2 \\
\%\end{array}$ & $\begin{array}{c}\text { As } \\
1 \\
\text { ppm }\end{array}$ & $\begin{array}{c}\text { Au } \\
3 \\
\text { ppm }\end{array}$ & $\begin{array}{c}\mathrm{Ba} \\
2 \\
\mathrm{ppm}\end{array}$ & $\begin{array}{c}\mathrm{Be} \\
2 \\
\mathrm{ppm}\end{array}$ & $\begin{array}{c}\mathrm{Bi} \\
1 \\
\mathrm{ppm}\end{array}$ & $\begin{array}{l}\text { Ca } \\
2 \\
\%\end{array}$ & $\begin{array}{c}\text { Cd } \\
1 \\
\text { ppm }\end{array}$ & $\begin{array}{c}\text { Ce } \\
2 \\
\text { ppm }\end{array}$ & $\begin{array}{c}\text { Co } \\
2 \\
\text { ppm }\end{array}$ & $\begin{array}{c}\mathrm{Cr} \\
2 \\
\mathrm{ppm}\end{array}$ & $\begin{array}{c}\mathrm{Cu} \\
1 \\
\mathrm{ppm}\end{array}$ & $\begin{array}{c}\mathrm{Cu} \\
2 \\
\mathrm{ppm}\end{array}$ & $\begin{array}{c}\text { Eu } \\
2 \\
\text { ppm }\end{array}$ & $\begin{array}{c}\mathrm{Fe} \\
2 \\
\%\end{array}$ \\
\hline 00AG005W & 62.721 & -148.441 & $\begin{array}{l}\text { Fine- to medium- grained feldspar-hornblende(?) } \\
\text { hypabyssal intrusion(?) or flow with lithic clasts }\end{array}$ & 0.4 & 8.385 & 5 & $<0.005$ & 660 & $<1$ & 1 & 4.295 & 0.07 & 52 & 19 & 83 & 36.9 & 35 & 3 & 5.89 \\
\hline 00AG007W & 62.724 & -148.444 & Very fine grained (pyrite) biotite-feldspar intrusion & 0.3 & 8.595 & 10 & $<0.005$ & 469 & $<1$ & $<1$ & 3.335 & 0.08 & 34 & 15 & 16 & 63.4 & 64 & 3 & 4.59 \\
\hline 00JS035W & 62.970 & -148.879 & $\begin{array}{l}\text { Fe-oxide coated, welded, banded (.5mm thick) } \\
\text { pale green and white felsic tuff }\end{array}$ & $<0.08$ & 7.115 & 5 & $<0.005$ & 2260 & 2 & $<1$ & 0.145 & 0.3 & 94 & $<2$ & $<2$ & 1.7 & $<2$ & $<2$ & 1.84 \\
\hline 00JS044V & 62.963 & -148.829 & $\begin{array}{l}\text { Fe-oxide and Mn-oxide layer in altered volcanic } \\
\text { feldspar porphyry }\end{array}$ & 0.5 & 5.78 & 9 & $<0.005$ & 1280 & 3 & $<1$ & 0.065 & 1.17 & 56 & 3 & 11 & 8.37 & 7 & $<2$ & 17.4 \\
\hline 00JS044W & 62.963 & -148.829 & $\begin{array}{l}\text { Wavy Fe-oxide enriched bands in chalky altered } \\
\text { felsic volcanic rock }\end{array}$ & $<0.08$ & 8.25 & 4 & $<0.005$ & 1810 & 2 & $<1$ & 0.53 & 0.18 & 65 & 3 & $<2$ & 5.65 & 5 & $<2$ & 1.48 \\
\hline 00JS049W & 62.961 & -148.887 & $\begin{array}{l}\text { Rare orange- and red-brown stained Kahiltna Fm. } \\
\text { argillite }\end{array}$ & 0.1 & 7.39 & 14 & $<0.005$ & 841 & $<1$ & $<1$ & 0.18 & 0.08 & 42 & 8 & 66 & 29 & 27 & $<2$ & 3.89 \\
\hline 00JS063W & 62.658 & -148.366 & Oragne-brown weathering siliceous argillite & 0.2 & 2.91 & 10 & $<0.005$ & 101 & $<1$ & 1 & 1.54 & 0.2 & 28 & $<2$ & 3 & 25.4 & 26 & $<2$ & 0.79 \\
\hline 00JS076W & 62.990 & -148.615 & $\begin{array}{l}\text { Orange-brown bands in chalky, altered volca- } \\
\text { nic(?) rock }\end{array}$ & $<0.08$ & 7.11 & 2 & $<0.005$ & 1440 & 2 & $<1$ & 0.745 & 0.17 & 58 & $<2$ & $<2$ & 4 & 4 & $<2$ & 2.59 \\
\hline 00SC016W & 62.731 & -148.391 & Sulfides in mafic(?) lava & $<0.08$ & 3.315 & 2 & $<0.005$ & 6170 & $<1$ & $<1$ & 0.57 & 0.07 & 38 & 6 & 10 & 23.2 & 22 & $<2$ & 2.37 \\
\hline 00SC030W & 62.990 & -148.806 & Pyrite in lithic-rich, gray biotite-quartz tuff & 0.1 & 7.96 & 13 & $<0.005$ & 1440 & 2 & $<1$ & 1.95 & 0.33 & 72 & 9 & 16 & 22.8 & 23 & 3 & 4.51 \\
\hline 00SC032W & 62.988 & -148.849 & $\begin{array}{l}\text { Locally pyritic dark, aphanitic volcanic rock, cut } \\
\text { by quartz veinlets }\end{array}$ & 0.4 & 8.16 & 18 & $<0.005$ & 205 & $<1$ & $<1$ & 8.06 & 0.11 & 32 & 42 & 70 & 158 & 167 & 2 & 7.96 \\
\hline 00SC036W & 63.004 & -148.887 & Pyritic fine-grained hornfels & 0.3 & 7.935 & 4 & $<0.005$ & 1030 & $<1$ & $<1$ & 0.38 & 0.14 & 63 & 25 & 51 & 63.2 & 59 & 3 & 5.77 \\
\hline 01AG022X & 62.655 & -148.430 & Trace pyrite in gray limestone & $<0.08$ & 2.47 & $<1$ & $<0.005$ & 20 & $<1$ & $<1$ & 8.725 & $<0.05$ & 19 & $<2$ & 3 & 3.39 & 14 & $<2$ & 0.59 \\
\hline 01JS006AX & 63.035 & -148.130 & $\begin{array}{l}\text { Dark red weathering, biotite-bearing metasiltstone } \\
\text { / argllite }\end{array}$ & 0.6 & 7.325 & 2 & 0.01 & 1550 & $<1$ & $<1$ & 0.505 & 0.13 & 47 & $<2$ & 41 & 40.5 & 45 & $<2$ & 1.1 \\
\hline 01JS058DX & 62.711 & -148.177 & Pyritic pale green-gray Nikolai mafic lava & $<0.08$ & 8.42 & $<1$ & 0.006 & 482 & $<1$ & $<1$ & 4.69 & $<0.05$ & $<5$ & 22 & 91 & 70.4 & 70 & $<2$ & 6.59 \\
\hline 01JS069BX & 62.814 & -148.804 & $\begin{array}{l}\text { Slightly pyritic, biotite-rich Fe-stained zone in } \\
\text { metasediments }\end{array}$ & 0.2 & 5.83 & $<1$ & 0.009 & 586 & $<1$ & $<1$ & 1.155 & $<0.05$ & 9 & 4 & 9 & 35.9 & 41 & $<2$ & 3.96 \\
\hline 01SC009EX & 62.656 & -148.374 & $\begin{array}{l}\text { Orange-weathering, chert, interbedded with } \\
\text { limestone and mafic sills }\end{array}$ & 0.2 & 1.453 & 9 & $<0.005$ & 136 & $<1$ & $<1$ & 0.147 & 0.05 & 19 & 2 & $<2$ & 29.1 & 32 & $<2$ & 1.04 \\
\hline 01SC017AX & 62.664 & -148.402 & Epidote-veined and altered microgabbro sill & $<0.08$ & 9.31 & 2 & 0.027 & 63 & $<1$ & $<1$ & 5.975 & $<0.05$ & $<5$ & 53 & 8 & 10.1 & 21 & $<2$ & 15.4 \\
\hline 02JS041Q & 63.000 & -148.716 & $\begin{array}{l}\text { Disseminated Fe-oxide in orange- weathering } \\
\text { siliceous tuff or fine-grained, altered flow }\end{array}$ & 4.2 & 6.266 & 6 & $<0.005$ & 2170 & 3 & $<1$ & 0.067 & 1.15 & 111 & $<2$ & 4 & 8.17 & 7 & $<2$ & 1.9 \\
\hline 02JS043P & 62.995 & -149.264 & $\begin{array}{l}\text { Fe-oxide stained bull quartz vein, with small } \\
\text { inclusions of mafic rock }\end{array}$ & 0.1 & 0.17 & $<1$ & $<0.005$ & 25 & $<1$ & $<1$ & 0.007 & 0.12 & $<5$ & 4 & 9 & 28.7 & 29 & $<2$ & 1.08 \\
\hline 02JS043X & 62.995 & -149.264 & $\begin{array}{l}\text { Band of 5-15\% pyrite layers and dissemina- } \\
\text { tions in dark gray siliceous siltstone; possibly } \\
\text { hornfelsed }\end{array}$ & 0.3 & 4.427 & 4 & $<0.005$ & 1050 & $<1$ & $<1$ & 0.071 & 0.4 & 17 & $<2$ & 10 & 37.6 & 35 & $<2$ & 1.59 \\
\hline 02JS050T & 63.035 & -148.940 & $\begin{array}{l}\text { Locally red-orange weathering, very fine-grained } \\
\text { quartz-biotite hornfels }\end{array}$ & 0.4 & 5.75 & 2 & $<0.005$ & 1850 & 1 & $<1$ & 0.355 & 0.41 & 48 & 6 & 76 & 64.3 & 62 & 2 & 3.35 \\
\hline 02RR001Z & 63.197 & -149.149 & Red-brown weathering, rhyolite porphyry dike & 1.8 & 6.11 & 5 & $<0.005$ & 158 & 9 & 1 & 0.063 & 0.47 & 36 & $<2$ & 4 & 12 & 13 & $<2$ & 0.95 \\
\hline 02SC002Z & 63.000 & -149.217 & $\begin{array}{l}\text { Fe-oxide stained portion of vuggy } 2 \mathrm{~m} \text { wide quartz } \\
\pm \text { calcite vein }\end{array}$ & 0.1 & 0.223 & 5 & $<0.005$ & 43 & $<1$ & $<1$ & 0.101 & 0.06 & $<5$ & 6 & 3 & 14 & 12 & $<2$ & 0.3 \\
\hline 02SC003Q & 63.116 & -149.301 & Mildly altered pyritic felsic dike & 0.2 & 6.881 & 8 & $<0.005$ & 1960 & 3 & $<1$ & 0.694 & 0.16 & 94 & $<2$ & 3 & 72.9 & 71 & 2 & 2.04 \\
\hline 02SC005Z & 63.116 & -148.940 & $\begin{array}{l}\text { Float of orange-weathering, altered felsic volcanic } \\
\text { rock at contact with granite }\end{array}$ & 1 & 7.127 & 89 & 0.012 & 248 & 4 & $<1$ & 0.049 & 0.36 & 102 & $<2$ & 4 & 11.3 & 13 & 3 & 3.35 \\
\hline 02SC026X & 63.023 & -149.178 & Felsic stock and dikes & 0.3 & 7.423 & $<1$ & $<0.005$ & 235 & 6 & $<1$ & 0.373 & 0.49 & 7 & $<2$ & 7 & 3.06 & 4 & $<2$ & 0.46 \\
\hline
\end{tabular}


[Analytical methods: 1, 10-element ICP-AES DIBK extraction; 2, 40-element ICP-AES total extraction; 3, fire assay-DCP-AES; 4, CVAA; 5, INAA]

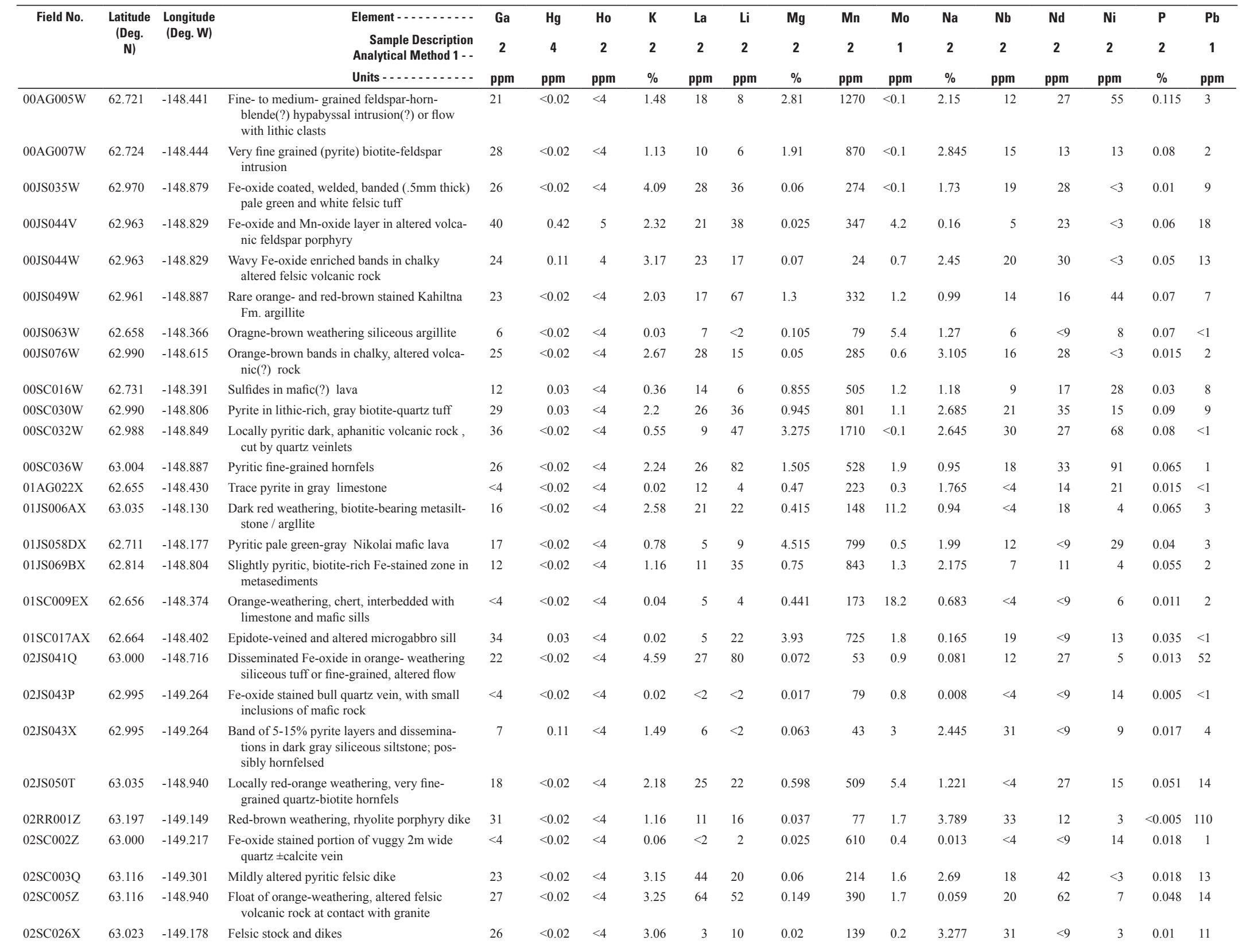


Table 2. Analytical data for quality-control samples from the northern Talkeetna Mountains, Alaska.

[Analytical methods: 1, 10-element ICP-AES DIBK extraction; 2, 40-element ICP-AES total extraction; 3, fire assay-DCP-AES; 4, CVAA; 5, INAA]

\begin{tabular}{|c|c|c|c|c|c|c|c|c|c|c|c|c|c|c|c|c|c|c|}
\hline Field No. & $\begin{array}{l}\text { Latitude } \\
\text { (Deg. } \\
\text { N) }\end{array}$ & $\begin{array}{l}\text { Longitude } \\
\text { (Deg. W) }\end{array}$ & $\begin{array}{r}\text { Element - } \begin{array}{c}\text { Sample Description } \\
\text { Analytical Method } 1 \text { - }\end{array} \\
\text { Units ............ }\end{array}$ & $\begin{array}{c}\mathrm{Pb} \\
2 \\
\end{array}$ & $\begin{array}{c}\mathrm{Sb} \\
1 \\
\end{array}$ & $\begin{array}{l}\text { Sc } \\
2 \\
\end{array}$ & $\begin{array}{c}\text { Sn } \\
2\end{array}$ & $\begin{array}{c}\mathrm{Sr} \\
2\end{array}$ & $\begin{array}{c}\text { Ta } \\
2\end{array}$ & $\begin{array}{c}\text { Th } \\
2\end{array}$ & 2 & $\begin{array}{l}\mathbf{U} \\
2\end{array}$ & $\begin{array}{l}v \\
2\end{array}$ & $\begin{array}{c}\mathbf{W} \\
5\end{array}$ & $\begin{array}{l}Y \\
2\end{array}$ & $\begin{array}{c}\mathrm{Yb} \\
2 \\
\end{array}$ & $\begin{array}{c}\mathrm{Zn} \\
1\end{array}$ & $\begin{array}{l}\mathrm{Zn} \\
2\end{array}$ \\
\hline & & & Units - ........... & $\mathrm{ppm}$ & ppm & ppm & $\mathrm{ppm}$ & $\mathrm{ppm}$ & $\mathrm{ppm}$ & $\mathrm{ppm}$ & $\%$ & $\mathrm{ppm}$ & $\mathrm{ppm}$ & $\mathrm{ppm}$ & ppm & $\mathrm{ppm}$ & $\mathrm{ppm}$ & ppm \\
\hline 00AG005W & 62.721 & -148.441 & $\begin{array}{l}\text { Fine- to medium- grained feldspar-horn- } \\
\text { blende(?) hypabyssal intrusion(?) or flow } \\
\text { with lithic clasts }\end{array}$ & $<4$ & 1 & 26 & $<50$ & 673 & $<40$ & $<6$ & 0.45 & $<100$ & 162 & 0.6 & 23 & 3 & 92.5 & 85 \\
\hline 00AG007W & 62.724 & -148.444 & $\begin{array}{l}\text { Very fine grained (pyrite) biotite-feldspar } \\
\text { intrusion }\end{array}$ & $<4$ & $<1$ & 26 & $<50$ & 801 & $<40$ & $<6$ & 0.46 & $<100$ & 197 & $<0.5$ & 21 & 2 & 70.8 & 65 \\
\hline 00JS035W & 62.970 & -148.879 & $\begin{array}{l}\text { Fe-oxide coated, welded, banded (.5mm thick) } \\
\text { pale green and white felsic tuff }\end{array}$ & 12 & 1 & 10 & $<50$ & 107 & $<40$ & 14 & 0.105 & $<100$ & 3 & 1.3 & 29 & 3 & 94.2 & 89 \\
\hline 00JS044V & 62.963 & -148.829 & $\begin{array}{l}\text { Fe-oxide and Mn-oxide layer in altered volca- } \\
\text { nic feldspar porphyry }\end{array}$ & 16 & 3 & 10 & $<50$ & 95 & $<40$ & 7 & 0.145 & $<100$ & 14 & 0.9 & 30 & 3 & 228 & 217 \\
\hline 00JS044W & 62.963 & -148.829 & $\begin{array}{l}\text { Wavy Fe-oxide enriched bands in chalky } \\
\text { altered felsic volcanic rock }\end{array}$ & 13 & $<1$ & 13 & $<50$ & 272 & $<40$ & 10 & 0.24 & $<100$ & 18 & 1 & 21 & 2 & 124 & 114 \\
\hline 00JS049W & 62.961 & -148.887 & $\begin{array}{l}\text { Rare orange- and red-brown stained Kahiltna } \\
\text { Fm. argillite }\end{array}$ & 9 & 2 & 14 & $<50$ & 90 & $<40$ & 7 & 0.325 & $<100$ & 172 & 2.6 & 8 & 1 & 99 & 91 \\
\hline 00JS063W & 62.658 & -148.366 & Oragne-brown weathering siliceous argillite & $<4$ & $<1$ & 5 & $<50$ & 28 & $<40$ & $<6$ & 0.115 & $<100$ & 98 & 0.5 & 11 & 1 & 16 & 17 \\
\hline 00JS076W & 62.990 & -148.615 & $\begin{array}{l}\text { Orange-brown bands in chalky, altered volca- } \\
\text { nic(?) rock }\end{array}$ & 5 & $<1$ & 13 & $<50$ & 233 & $<40$ & 9 & 0.15 & $<100$ & 2 & $<0.5$ & 22 & 2 & 105 & 122 \\
\hline 00SC016W & 62.731 & -148.391 & Sulfides in mafic(?) lava & 6 & $<1$ & 11 & $<50$ & 100 & $<40$ & $<6$ & 0.195 & $<100$ & 52 & 2.2 & 12 & 2 & 47.6 & 45 \\
\hline 00SC030W & 62.990 & -148.806 & Pyrite in lithic-rich, gray biotite-quartz tuff & 10 & 2 & 20 & $<50$ & 335 & $<40$ & 9 & 0.45 & $<100$ & 118 & 1.5 & 25 & 2 & 127 & 117 \\
\hline 00SC032W & 62.988 & -148.849 & $\begin{array}{l}\text { Locally pyritic dark, aphanitic volcanic rock, } \\
\text { cut by quartz veinlets }\end{array}$ & $<4$ & $<1$ & 45 & $<50$ & 274 & $<40$ & $<6$ & 1.13 & $<100$ & 338 & 0.9 & 35 & 3 & 90.3 & 84 \\
\hline 00SC036W & 63.004 & -148.887 & Pyritic fine-grained hornfels & $<4$ & $<1$ & 25 & $<50$ & 217 & $<40$ & 10 & 0.565 & $<100$ & 234 & 1.2 & 7 & 1 & 108 & 119 \\
\hline 01AG022X & 62.655 & -148.430 & Trace pyrite in gray limestone & $<4$ & $<1$ & 6 & $<50$ & 139 & $<40$ & $<6$ & 0.143 & $<100$ & 47 & 0.9 & 14 & $<1$ & 11.1 & 13 \\
\hline 01JS006AX & 63.035 & -148.130 & $\begin{array}{l}\text { Dark red weathering, biotite-bearing metasilt- } \\
\text { stone / argllite }\end{array}$ & 12 & $<1$ & 8 & $<50$ & 245 & $<40$ & 7 & 0.127 & $<100$ & 164 & 2.7 & 8 & 2 & 21.5 & 24 \\
\hline 01JS058DX & 62.711 & -148.177 & Pyritic pale green-gray Nikolai mafic lava & 5 & $<1$ & 49 & $<50$ & 196 & $<40$ & $<6$ & 0.517 & $<100$ & 293 & 0.8 & 18 & 2 & 42 & 60 \\
\hline 01JS069BX & 62.814 & -148.804 & $\begin{array}{l}\text { Slightly pyritic, biotite-rich Fe-stained zone in } \\
\text { metasediments }\end{array}$ & 6 & $<1$ & 12 & $<50$ & 315 & $<40$ & $<6$ & 0.27 & $<100$ & 96 & 0.8 & 10 & 1 & 97.7 & 89 \\
\hline 01SC009EX & 62.656 & -148.374 & $\begin{array}{l}\text { Orange-weathering, chert, interbedded with } \\
\text { limestone and mafic sills }\end{array}$ & $<4$ & $<1$ & 4 & $<50$ & 23 & $<40$ & $<6$ & 0.081 & $<100$ & 59 & 1.4 & 9 & 1 & 11 & 12 \\
\hline 01SC017AX & 62.664 & -148.402 & Epidote-veined and altered microgabbro sill & $<4$ & $<1$ & 50 & $<50$ & 401 & $<40$ & $<6$ & 0.407 & $<100$ & 458 & 0.9 & 21 & 2 & 47.9 & 49 \\
\hline 02JS041Q & 63.000 & -148.716 & $\begin{array}{l}\text { Disseminated Fe-oxide in orange- weathering } \\
\text { siliceous tuff or fine-grained, altered flow }\end{array}$ & 52 & 4 & 12 & $<50$ & 34 & $<40$ & 10 & 0.136 & $<100$ & 8 & 1.4 & 16 & 2 & 186 & 187 \\
\hline 02JS043P & 62.995 & -149.264 & $\begin{array}{l}\text { Fe-oxide stained bull quartz vein, with small } \\
\text { inclusions of mafic rock }\end{array}$ & $<4$ & $<1$ & $<2$ & $<50$ & $<2$ & $<40$ & $<6$ & 0.009 & $<100$ & 9 & $<0.5$ & $<2$ & $<1$ & 90 & 87 \\
\hline 02JS043X & 62.995 & -149.264 & $\begin{array}{l}\text { Band of } 5-15 \% \text { pyrite layers and dissemina- } \\
\text { tions in dark gray siliceous siltstone; pos- } \\
\text { sibly hornfelsed }\end{array}$ & $<4$ & 2 & 5 & $<50$ & 114 & $<40$ & $<6$ & 0.191 & $<100$ & 61 & $<0.5$ & 19 & 3 & 73.4 & 72 \\
\hline 02JS050T & 63.035 & -148.940 & $\begin{array}{l}\text { Locally red-orange weathering, very fine- } \\
\text { grained quartz-biotite hornfels }\end{array}$ & 10 & $<1$ & 18 & $<50$ & 111 & $<40$ & $<6$ & 0.14 & $<100$ & 217 & 1.9 & 6 & 1 & 87.9 & 81 \\
\hline 02RR001Z & 63.197 & -149.149 & Red-brown weathering, rhyolite porphyry dike & 100 & 1 & 4 & $<50$ & 31 & $<40$ & 18 & 0.046 & $<100$ & $<2$ & 1 & 27 & 6 & 71.5 & 67 \\
\hline $02 \mathrm{SC} 002 \mathrm{Z}$ & 63.000 & -149.217 & $\begin{array}{l}\text { Fe-oxide stained portion of vuggy } 2 \mathrm{~m} \text { wide } \\
\text { quartz } \pm \text { calcite vein }\end{array}$ & $<4$ & $<1$ & $<2$ & $<50$ & 12 & $<40$ & $<6$ & 0.005 & $<100$ & 4 & $<0.5$ & $<2$ & $<1$ & 10.8 & 12 \\
\hline 02SC003Q & 63.116 & -149.301 & Mildly altered pyritic felsic dike & 11 & $<1$ & 21 & $<50$ & 209 & $<40$ & 10 & 0.156 & $<100$ & 8 & $<0.5$ & 32 & 3 & 24.2 & 23 \\
\hline 02SC005Z & 63.116 & -148.940 & $\begin{array}{l}\text { Float of orange-weathering, altered felsic } \\
\text { volcanic rock at contact with granite }\end{array}$ & 11 & $<1$ & 41 & $<50$ & 12 & $<40$ & 7 & 0.296 & $<100$ & 34 & 3.4 & 37 & 3 & 116 & 121 \\
\hline 02SC026X & 63.023 & -149.178 & Felsic stock and dikes & 13 & $<1$ & $<2$ & $<50$ & 82 & $<40$ & $<6$ & $<0.005$ & $<100$ & $<2$ & 0.9 & $<2$ & $<1$ & 120 & 126 \\
\hline
\end{tabular}


Table 3. Analytical methods and determination limits for rock samples from the northern Talkeetna Mountains, Alaska.

\begin{tabular}{|c|c|c|c|c|c|c|c|c|c|}
\hline \multirow{2}{*}{ Element } & \multirow{2}{*}{$\begin{array}{l}\text { Analytical } \\
\text { method }\end{array}$} & \multicolumn{4}{|c|}{ Determination limits } & \multirow{2}{*}{ Units } & \multicolumn{2}{|c|}{ Data Statistics } & \multirow{2}{*}{$\begin{array}{c}\text { Crustal } \\
\text { abundance }\end{array}$} \\
\hline & & Lower & $n^{1}$ & Upper & $n^{2}$ & & Max & Median & \\
\hline $\mathrm{Ag}$ & ICP10 & 0.08 & 76 & 400 & 0 & ppm & 116 & 0.1 & 0.07 \\
\hline $\mathrm{Al}$ & ICP40 & 0.005 & 0 & 50 & 0 & percent & 9.735 & 6.875 & 8.2 \\
\hline As & ICP10 & 1 & 40 & 6,000 & 1 & ppm & $>6,000$ & 5 & 1.8 \\
\hline $\mathrm{Au}$ & FA & 0.005 & 158 & & 0 & ppm & 7.64 & $<0.005$ & 0.003 \\
\hline $\mathrm{Ba}$ & ICP40 & 1 & 0 & 35,000 & 0 & ppm & 13,480 & 654 & 425 \\
\hline $\mathrm{Be}$ & ICP40 & 1 & 109 & 5,000 & 0 & ppm & 10 & $<1$ & 2.8 \\
\hline $\mathrm{Bi}$ & ICP10 & 1 & 164 & 6,000 & 0 & ppm & 18 & $<1$ & 0.17 \\
\hline $\mathrm{Ca}$ & ICP40 & 0.005 & 2 & 50 & 0 & percent & 26.7 & 0.755 & 4.1 \\
\hline $\mathrm{Cd}$ & ICP10 & 0.05 & 51 & 500 & 0 & ppm & 126 & 0.13 & 0.2 \\
\hline $\mathrm{Ce}$ & ICP40 & 5 & 33 & 50,000 & 0 & $\mathrm{ppm}$ & 2,710 & 29 & 67 \\
\hline Co & ICP40 & 2 & 62 & 25,000 & 0 & ppm & 226 & 7 & 25 \\
\hline $\mathrm{Cr}$ & ICP40 & 2 & 32 & 25,000 & 0 & ppm & 303 & 8 & 100 \\
\hline $\mathrm{Cu}$ & ICP40 & 2 & 4 & 15,000 & 0 & ppm & 46,870 & 28 & 55 \\
\hline $\mathrm{Eu}$ & ICP40 & 2 & 139 & 5,000 & 0 & ppm & 281 & $<2$ & 1.2 \\
\hline $\mathrm{Fe}$ & ICP40 & 0.02 & 0 & 25 & 0 & percent & 50.01 & 3.25 & 5.6 \\
\hline $\mathrm{Ga}$ & ICP40 & 4 & 17 & 50,000 & 0 & ppm & 57 & 20 & 15 \\
\hline $\mathrm{Hg}$ & CVAA & 0.02 & 150 & -- & 0 & $\mathrm{ppm}$ & 1.56 & $<0.02$ & 0.08 \\
\hline Но & ICP40 & 4 & 184 & 5,000 & 0 & ppm & 163 & $<4$ & 1.5 \\
\hline K & ICP40 & 0.01 & 3 & 50 & 0 & percent & 6.76 & 1.26 & 2.1 \\
\hline $\mathrm{La}$ & ICP40 & 2 & 26 & 50,000 & 0 & ppm & 1,210 & 13 & 25 \\
\hline $\mathrm{Li}$ & ICP40 & 2 & 11 & 50,000 & 0 & ppm & 188 & 18 & 20 \\
\hline $\mathrm{Mg}$ & ICP40 & 0.005 & 0 & 5 & 0 & percent & 6.728 & 0.67 & 2.3 \\
\hline $\mathrm{Mn}$ & ICP40 & 4 & 1 & 50,000 & 0 & ppm & 6,810 & 488 & 950 \\
\hline Mo & ICP10 & 0.1 & 18 & 900 & 0 & ppm & 23.6 & 0.9 & 1.5 \\
\hline $\mathrm{Na}$ & ICP40 & 0.005 & 0 & 50 & 0 & percent & 4.355 & 1.439 & 2.4 \\
\hline $\mathrm{Nb}$ & ICP40 & 4 & 49 & 50,000 & 0 & ppm & 57 & 11 & 20 \\
\hline $\mathrm{Nd}$ & ICP40 & 9 & 45 & 50,000 & 0 & ppm & 2,230 & 19 & 28 \\
\hline $\mathrm{Ni}$ & ICP40 & 3 & 55 & 50,000 & 0 & ppm & 205 & 11 & 75 \\
\hline $\mathrm{P}$ & ICP40 & 0.005 & 16 & 50 & 0 & percent & 2.783 & 0.035 & 0.1 \\
\hline $\mathrm{Pb}$ & ICP10 & 1 & 47 & 6,000 & 0 & ppm & 1,660 & 4 & 12.5 \\
\hline $\mathrm{Sb}$ & ICP10 & 1 & 133 & 6,000 & 0 & ppm & 115 & $<1$ & 0.2 \\
\hline $\mathrm{Sc}$ & ICP40 & 2 & 17 & 50,000 & 0 & ppm & 57 & 12 & 22 \\
\hline $\mathrm{Sr}$ & ICP40 & 2 & 1 & 15,000 & 0 & ppm & 1,550 & 126 & 375 \\
\hline $\mathrm{Th}$ & ICP40 & 6 & 140 & 50,000 & 0 & ppm & 17 & $<6$ & 9.6 \\
\hline $\mathrm{Ti}$ & ICP40 & 0.005 & 5 & 25 & 0 & percent & 2.261 & 0.187 & 0.57 \\
\hline $\mathrm{V}$ & ICP40 & 2 & 13 & 30,000 & 0 & ppm & 651 & 95 & 135 \\
\hline W & INAA & 0.5 & 41 & -- & 0 & ppm & 19.2 & 1.1 & 1.5 \\
\hline $\mathrm{Y}$ & ICP40 & 2 & 13 & 25,000 & 0 & ppm & 4,170 & 19 & 33 \\
\hline $\mathrm{Yb}$ & ICP40 & 1 & 34 & 5,000 & 0 & ppm & 334 & 2 & 3 \\
\hline $\mathrm{Zn}$ & ICP40 & 2 & 2 & 15,000 & 0 & ppm & 18,900 & 70 & 70 \\
\hline
\end{tabular}

\footnotetext{
1 Number of samples below lower determination limit.

${ }^{2}$ Number of samples above upper determination limit.

3 From Krauskopf, 1979
} 
Produced in the Menlo Park Publishing Service Center, California Manuscript approved for publication September 8, 2011 Text edited by Peter Stauffer Layout and design by Judy Weathers 
